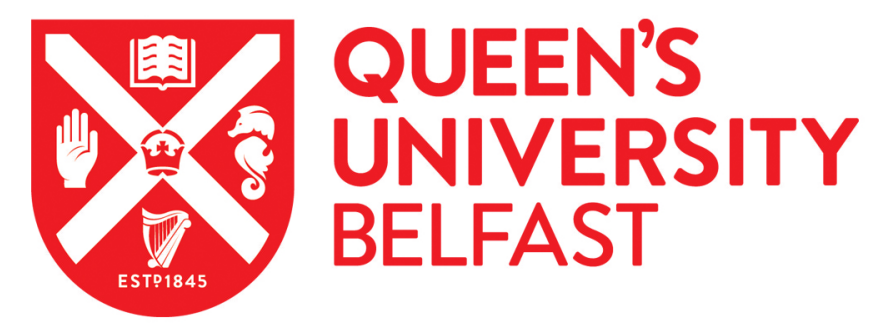

\title{
A systematic review of older patients' experiences and perceptions of communication about managing medication across transitions of care
}

Ozavci, G., Bucknall, T., Woodward-Kron, R., Hughes, C., Jorm, C., Joseph, K., \& Manias, E. (2020). A systematic review of older patients' experiences and perceptions of communication about managing medication across transitions of care. Research in Social and Administrative Pharmacy. https://doi.org/10.1016/j.sapharm.2020.03.023

Published in:

Research in Social and Administrative Pharmacy

Document Version:

Peer reviewed version

Queen's University Belfast - Research Portal:

Link to publication record in Queen's University Belfast Research Portal

Publisher rights

Copyright 2020 Elsevier.

This manuscript is distributed under a Creative Commons Attribution-NonCommercial-NoDerivs License

(https://creativecommons.org/licenses/by-nc-nd/4.0/), which permits distribution and reproduction for non-commercial purposes, provided the author and source are cited.

\section{General rights}

Copyright for the publications made accessible via the Queen's University Belfast Research Portal is retained by the author(s) and / or other copyright owners and it is a condition of accessing these publications that users recognise and abide by the legal requirements associated with these rights.

Take down policy

The Research Portal is Queen's institutional repository that provides access to Queen's research output. Every effort has been made to ensure that content in the Research Portal does not infringe any person's rights, or applicable UK laws. If you discover content in the Research Portal that you believe breaches copyright or violates any law, please contact openaccess@qub.ac.uk. 
1 ABSTRACT

2 Background

3 Communication about managing medications may be difficult when older people move across

4 transitions of care. Communication breakdowns may result in medication discrepancies or 5 incidents.

\section{Objective}

7 The aim of this systematic review was to explore older patients' experiences and perceptions

8 of communication about managing medications across transitions of care.

9 Design

10 A systematic review

11 Methods

12 A comprehensive review was conducted of qualitative, quantitative and mixed method studies 13 using CINAHL Complete, MEDLINE, Embase and PsycINFO, Web of Science, INFORMIT 14 and Scopus. These databases were searched from inception to 14.12.2018. Key article cross15 checking and hand searching of reference lists of included papers were also undertaken. 16 Inclusion criteria: studies of the medication management perspectives of people aged 65 or older who transferred between care settings. These settings comprised patients' homes, residential aged care and acute and subacute care. Only English language studies were included. Comments, case reports, systematic reviews, letters, editorials were excluded. Thematic analysis was undertaken by synthesising qualitative data, whereas quantitative data

21 were summarised descriptively. Methodological quality was assessed with the Mixed Methods 22 Appraisal Tool.

\section{Results}

24 The final review comprised 33 studies: 12 qualitative, 17 quantitative and 4 mixed methods studies. Twenty studies addressed the link between communication and medication discrepancies; ten studies identified facilitators of self-care through older patient engagement; 18 studies included older patients’ experiences with health professionals about their medication regimen; and, 13 studies included strategies for communication about medications with older patients. Poor communication between primary and secondary care settings was reported as a reason for medication discrepancy before discharge. Older patients expected ongoing and 
31 tailored communication with providers and timely, accurate and written information about their 32 medications before discharge or available for the post-discharge period.

\section{Conclusions}

34 Communication about medications was often found to be ineffective. Most emphasis was 35 placed on older patients' perspectives at discharge and in the post-discharge period. There was

36 little exploration of older patients' views of communication about medication management on 37 admission, during hospitalisation, or transfer between settings.

\section{Keywords}

39 Communication; Medication management; Transitions of care; Older patients; Patient 40 experience; Systematic review 


\section{Introduction}

Transitions of care involve movements of patients between health care settings, within different levels of care, and introduce comprise different health professionals managing their care $^{1}$. Older people are likely to experience multiple chronic conditions, sudden health status changes, and problems relating to their medication management. Care transition pathways of older patients can vary in nature, and include transfers from home-to-hospital, hospital-tohome, different settings of care within one hospital, or movements between different hospitals, home-to-skilled care facilities, skilled care facilities-to-home, and home-hospital-skilled care facilities ${ }^{1}$.

Older patients are at increased risk of experiencing medication discrepancies across transitions of care because of possible breakdowns in communication about managing their medications ${ }^{2-5}$. Medication discrepancies are any inconsistencies between medications as patients move between different environments. These medication discrepancies are often poorly communicated or inadequately documented in patients' medical records. There could be unintentional and intentional medication discrepancies. Unintentional discrepancies stem from unplanned medication changes, whereas intentional medication discrepancies happen where health professionals make the changes to the medication regimens depending on alterations in patients' clinical manifestations. ${ }^{6}$ Medication discrepancies can involve omission of medication, additional medication, or change in dose, route or administration of a medication 7, 8 . An incomplete or inaccurate medication history at any point during a patient's care can lead to medication discrepancies ${ }^{9-12}$. Patients who move between transitions of care can experience medication errors. Medication errors are defined as any preventable event that may cause or lead to inappropriate medication use or patient harm while the medication is in the control of the health care professional, patient, or consumer ${ }^{13}$. Medication discrepancies and medication errors can lead to adverse drug events, which are adverse events that result in patient harm ${ }^{15}$. Past research has shown medication discrepancies are more prevalent during hospital admission and discharge because of poor communication and inadequate information transfer ${ }^{14-18}$. Previous studies have also shown that the lack of information conveyed about medication changes was also common when patients moved from the emergency department to medical wards ${ }^{19-21}$.

Patients with polypharmacy and multimorbidities are likely to experience problems associated with medication management during care transitions. These problems can involve patients not receiving needed medication or taking unnecessary medication, improper 
administration of medication, overuse or underuse of medication and the use of medication for an excessive or insufficient duration ${ }^{22}$. Miscommunication between patients and health professionals, as well as amongst health professionals of different disciplines is the primary reason for medication management problems across care transitions ${ }^{3,5}$. Within the context of busy work environments in which health professionals work, such as pharmacists, physicians and nurses inappropriate reporting and poor communication about medications are likely to happen $^{23}$. Poor communication about medications is particularly of concern at the time of admission to and discharge from hospital, which can lead to increased readmissions, adverse drug events ${ }^{5}$ and medication errors ${ }^{24,25}$. Precise, clear and comprehensive communication of new prescribed, ceased or changed medications during hospitalization or on patients' transfer between environments requires interdisciplinary collaboration between pharmacists, physicians, and nurses in hospitals and also primary health care providers ${ }^{26}$. Particularly, pharmacists play an integral role in communicating medication knowledge during patients' transitions of care by conducting medication reviews and medication reconciliation, providing patient-centred education, resolving many medication discrepancies with doctors, organising telephone follow-ups with patients or primary care providers upon discharge ${ }^{27-29}$.

Communication is a cyclical process of sending, receiving, and obtaining feedback in a timely and accurate manner, and also understanding what information is being conveyed between individuals ${ }^{30,31}$. Communication can fail in high-task situations during patient transfer and at critical junctures, when health professionals are under stress or interrupted during an episode of communication. This communication failure can compromise the completeness and accuracy of information being transferred ${ }^{31}$. Previous studies also reported different barriers to patients undertaking medication communication with health care providers, such as the presence of unpredictable discharges ${ }^{32}$, chaotic and busy patient admissions ${ }^{33}$, lack of availability of medication information at admissions ${ }^{34,35}$, and lack of explanation of new medications by health care providers ${ }^{32}$. We defined communication about medication as the exchange and understanding of information between older people, their families and health care team members by verbal, non-verbal, electronic and written means. Medication management refers to activities relating to making decisions to prescribe medications, administrating medications, reviewing and recording medication orders, issuing, distributing and storing medications, as well as provision and transfer of information about medications. The patient is the focus of these medication management activities, especially when they are self-medicating ${ }^{36}$. Communication about medications is important because it affects patient satisfaction and adherence with medication instructions, making them feel more valued, 
supported, and respected. Effective communication enables patients to take a more active role in managing their medications ${ }^{31}$.

111 In the era of digitalization, health care systems have involved shifting from paper to

112 electronic health record processes to facilitate timely sharing of high-quality information across

113 transition of care ${ }^{37}$. However, use of electronic processes can have unintended consequences

114 in managing medications, leading to medication discrepancies and medication errors, which

115 ultimately produce patient harm as a result of system or user-related factors ${ }^{38}$. Medications that 116 need to be prescribed may be missing in electronic admission reports and discharge summaries, 117 incorrect medications may be supplied through electronic dispensing areas, and incorrect 118 medications may be selected and supplied to patients when discharged home ${ }^{38}$. Particularly, 119 differences in the vendor systems that do not communicate with each other can lead to a lack 120 of shared information when patients are transferred between different hospitals. Electronic 121 systems may cause a communication failure of the about reconciling the medication regimen 122 or checking the indication for newly prescribed medications ${ }^{1,39}$.

123 There have been no systematic reviews exploring older patients' own experiences and 124 perceptions of communication about managing medications across transitions of care. Previous 125 systematic reviews have examined interventions designed to improve transitional care of older 126 patients mainly at the point of discharge ${ }^{40,41}$ or transfer between acute and subacute settings

12742 . Other reviews have examined the application of transitional care models to specific patient 128 groups such as older patients with heart disease or stroke ${ }^{43-45}$. In some reviews, focus has been 129 placed on strategies promoting safe transitions for older people across settings ${ }^{40,41}$. One 130 systematic review has examined interventions focused on managing medication on admission 131 and discharge ${ }^{46}$. Most emphasis has been placed on the classification of medication 132 discrepancies that occur across transitions of care without considering older patients' 133 perspectives about communication processes involved ${ }^{47-49}$.

134 In view of the value of patient-centred care ${ }^{50}$, it is important to consider the perspectives 135 of older patients relating to communication about medication management at transitions of 136 care. Therefore, the aim of this systematic review was to examine older patients' experiences and perceptions of communication about managing medications across transitions of care.

\section{Methods}

\subsection{Design}

A systematic review of qualitative, quantitative and mixed method studies was conducted. The protocol of this systematic literature review was registered in PROSPERO 
143 (CRD42018094287). The Mixed Methods Appraisal tool was used to appraise the 144 methodological quality of different study designs. The PRISMA statement guided conduct of the systematic review ${ }^{51}$.

\subsection{Search Methods}

A comprehensive search was undertaken of electronic bibliographic databases from the date of their inception to 14.12.2018. Identified keywords were used as search terms for all included databases. Keywords used as search terms related to: transitions of care (e.g. transition point*, transfer, continuity of care, handoff), medication management (e.g. medication reconciliation, medication error), communication (e.g. conversation, consultation), older patients (aged, elderly, geriatric, older people, older adults) and care settings (e.g. hospitals, wards, care settings). MeSH, EMTREE and CINAHL Headings were utilized as predefined terms when performing the search in the databases. We also performed a free-text search after determining alternative terms for the identified key concepts. Each group of keywords was searched individually, and then combined. A search was conducted separately for each of the following databases: CINAHL Complete, MEDLINE, Embase, PsycINFO, Web of Science and INFORMIT. Key article cross-checking was conducted, and the reference lists of the most cited identified articles were assessed in Scopus to locate additional relevant articles. For the reference list search of most cited articles, the titles of papers in their reference lists were examined, and the abstracts of these papers were checked against inclusion and exclusion criteria. The inclusion criteria for the systematic review were used as the threshold for making decisions about the possible of papers in the reference lists. Hand searching was undertaken of reference lists of included articles and of relevant journals.

The overall objective was to explore older patients' experiences and perceptions of communication about managing medications across transitions of care. Therefore, inclusion criteria comprised empirical studies that were conducted using any research designs investigating communicating about managing medications across transitions of care. Research needed to focus on older people's perceptions or experiences to be included. Older people comprised individuals aged 65 years and older who were situated in any care settings, such as acute care hospitals, geriatric rehabilitation, residential aged care as well as home settings.

172 Exclusion criteria involved the papers not written in English as well as reviews, letters, 173 commentaries, case reports, editorials and conference abstracts. In this context, communication 174 involved the exchange of information about medications that occurred between older patients and other individuals by verbal, non-verbal, electronic and written means. All types of research 
designs were eligible for inclusion. Comments, letters, editorials conference abstracts, case reports and studies not in English were excluded.

\subsection{Search Outcomes}

In all, 1352 titles were identified through database searching and the final review comprised 33 studies. Results of the searches and screening are shown in a PRISMA flow diagram (Figure 1).

\subsection{Quality appraisal}

The Mixed Methods Appraisal Tool (MMAT) was utilised to appraise the methodological quality of included studies. Three methodological domains were considered: qualitative, quantitative (randomised, non-randomised, descriptive) and mixed methods studies. Included papers were assessed at the study level using the MMAT depending on their research designs, comprising qualitative, randomized, non-randomized, quantitative descriptive and mixed methods designs. Every study was evaluated according to five different questions relating to research design quality. Two investigators assessed the included papers independently according to the MMAT, any discrepancies were discussed, and consensus was reached. None of the papers were excluded from data synthesis because of the score they obtained in the MMAT. Information obtained from the MMAT assessment helped the authors make judgments about studies' methodological quality. Finally, studies were assigned an overall quality score ranging from $(0 / 5)$ to $(5 / 5)$ based on methodological quality criteria ${ }^{52}$. No studies were excluded because of the quality score. MMAT findings identified that 23 studies had a score of 5/5, 5 studies had a score of 4/5, one study received score of 3/5, 2 studies had a score of 2/5, and 2 papers obtained a score of $1 / 5$. Characteristics of all studies are provided in Table 1.

\subsection{Data Abstraction}

One reviewer undertook the database searches. Search terms and the approach used for the database searches were independently checked by two university librarians. Titles and abstracts of articles were reviewed independently by two reviewers against the inclusion and exclusion criteria to identify potentially relevant articles. In order to facilitate article screening, Rayyan Qatar Computing Research Institute (QCRI) software was utilised. Relevant systematic reviews were checked to ensure if there were further missed papers related to this review. After independent abstract review, discrepancies were resolved by consensus. Full texts of articles were sourced and reviewed for inclusion by the same two independent reviewers. Included papers were imported into EndNote, version X8. 
210 Extraction of data from included studies, such as sample descriptions and relevant

211 findings, was undertaken by one reviewer using a piloted extraction form. The key data

212 extracted were examined by a second reviewer to ensure accuracy, and discrepancies were

213 resolved by negotiation. 
Table 1 Characteristics of included studies

\begin{tabular}{|c|c|c|c|c|c|c|}
\hline $\begin{array}{l}\text { Author, year, } \\
\text { country }\end{array}$ & Study Purpose & $\begin{array}{l}\text { Methodology/Data } \\
\text { collection }\end{array}$ & Sample Size & $\begin{array}{c}\text { Setting/ Direction of } \\
\text { Transfer }\end{array}$ & Key Findings & $\begin{array}{l}\text { Quality } \\
\text { Assessment } \\
\text { Scores }\end{array}$ \\
\hline $\begin{array}{l}\text { Allen, et al. } \\
(2018)^{53} \\
\text { Australia }\end{array}$ & $\begin{array}{l}\text { Describing } \\
\text { patients' cares' } \\
\text { experiences of } \\
\text { transitions of } \\
\text { care across } \\
\text { subacute, acute } \\
\text { and community } \\
\text { settings. }\end{array}$ & $\begin{array}{l}\text { Qualitative } \\
\text { Descriptive Study } \\
\text { Data collection: } \\
\text { Semi-structured } \\
\text { interviews. }\end{array}$ & $\begin{array}{l}13 \text { Patients } \\
7 \text { Carers }\end{array}$ & $\begin{array}{l}\text { Metropolitan public } \\
\text { health-care network } \\
\text { Transition from } \\
\text { hospital to home }\end{array}$ & $\begin{array}{l}\text { Patients valued the information about their discharge medications by } \\
\text { hospital pharmacist. } \\
\text { Patients sought for information about medication changes and the } \\
\text { reason for those changes. } \\
\text { Some patients perceived that hospital doctors decided discharge } \\
\text { medications without understanding medications prescribed by other } \\
\text { medical doctors. } \\
\text { Older patient sought for reassurance, supportive relationship with } \\
\text { cares and family members across transitions of care. }\end{array}$ & $5 / 5$ \\
\hline $\begin{array}{l}\text { Chiu, et al. } \\
(2018)^{54} \text {, Hong } \\
\text { Kong }\end{array}$ & $\begin{array}{l}\text { Determining } \\
\text { whether } \\
\text { pharmacist } \\
\text { medication } \\
\text { review could } \\
\text { decrease } \\
\text { inappropriate } \\
\text { medications } \\
\text { and hospital } \\
\text { readmissions } \\
\text { among older } \\
\text { inpatients. }\end{array}$ & $\begin{array}{l}\text { Non-randomised } \\
\text { controlled trial } \\
\text { Data Collection: } \\
\text { Medication } \\
\text { appropriateness } \\
\text { assessed by } \\
\text { Medication } \\
\text { Appropriateness } \\
\text { Index. } \\
\text { Unscheduled } \\
\text { revisit to hospitals. }\end{array}$ & $\begin{array}{l}212 \text { patients } \\
104 \text { control } \\
108 \\
\text { intervention }\end{array}$ & $\begin{array}{l}\text { Geriatric unit of a } \\
\text { local hospital. } \\
\text { From the admission } \\
\text { to the discharge. }\end{array}$ & $\begin{array}{l}\text { A pharmacist-led medication review reduced the number of } \\
\text { inappropriate medications and unintended readmissions. } \\
\text { Inappropriate medication use was lower in intervention group }(28.0 \% \\
\text { vs } 56.4 \% \text {; } t \text {-test=result not stated, } \mathrm{P}<0.001) \text {. } \\
\text { Hospital readmission was lower in the intervention group }(13.2 \% \text { vs } \\
29.1 \% \text {, t-test=result not stated, } \mathrm{P}<0.001) \text {. }\end{array}$ & $4 / 5$ \\
\hline $\begin{array}{l}\text { Gadbois, et al. } \\
(2018)^{55} \text {, USA }\end{array}$ & $\begin{array}{l}\text { Understanding } \\
\text { the experiences } \\
\text { of patients who } \\
\text { transferred } \\
\text { from hospitals } \\
\text { to skilled } \\
\text { nursing facilities } \\
\text { by obtaining } \\
\text { insights from } \\
\text { patients, facility } \\
\text { staff. }\end{array}$ & $\begin{array}{l}\text { Qualitative Study } \\
\text { Data Collection: } \\
\text { Interviews with } \\
\text { patients, staff and } \\
\text { hospital staff. }\end{array}$ & $\begin{array}{l}138 \text { hospital } \\
\text { and skilled } \\
\text { nursing } \\
\text { facility staff, } \\
98 \text { patients } \\
\text { or/and their } \\
\text { family } \\
\text { members. }\end{array}$ & $\begin{array}{l}\text { Hospital, Skilled } \\
\text { Nursing Facility Staff } \\
\text { Discharge from } \\
\text { hospital to skilled } \\
\text { nursing facility }\end{array}$ & $\begin{array}{l}\text { Medication errors were associated with rushed transition from } \\
\text { hospital to skilled nursing facility. } \\
\text { Inaccurate information transfer between hospital and nursing facility } \\
\text { led to patient dissatisfaction with medication reconciliation. }\end{array}$ & $5 / 5$ \\
\hline
\end{tabular}




\begin{tabular}{|c|c|c|c|c|c|}
\hline $\begin{array}{l}\text { Barnett, et al. } \\
(2017)^{56} \text {, UK }\end{array}$ & $\begin{array}{l}\text { Investigating } \\
\text { the effect of the } \\
\text { pharmacy } \\
\text { integrated } \\
\text { medicines } \\
\text { management } \\
\text { service on the } \\
\text { rate of } \\
\text { preventable } \\
\text { medicines- } \\
\text { related } \\
\text { readmission } \\
\text { within } 30 \text { days } \\
\text { of discharge. }\end{array}$ & $\begin{array}{l}\text { Retrospective } \\
\text { Clinical Audit } \\
\text { Data Collection: } \\
\text { Retrospective data } \\
\text { collection, } \\
\text { Collection of 30- } \\
\text { Day readmission } \\
\text { data using the } \\
\text { hospital admissions } \\
\text { programme. } \\
\text { Review of } \\
\text { electronic } \\
\text { discharge } \\
\text { summaries. }\end{array}$ & 744 patients & $\begin{array}{l}\text { District general } \\
\text { hospital. } \\
\text { On admission, during } \\
\text { hospital stay and } \\
\text { post-discharge } \\
\text { follow up. }\end{array}$ & $\begin{array}{l}\text { Pharmacy integrated medicines management service team in hospital } \\
\text { was effective in reducing preventable medicines-related readmission } \\
\text { in older patients. }\end{array}$ \\
\hline $\begin{array}{l}\text { Jeffs, et al. } \\
(2017)^{57} \\
\text { Canada }\end{array}$ & $\begin{array}{l}\text { Exploring older } \\
\text { patients', } \\
\text { perceptions } \\
\text { with the } \\
\text { information } \\
\text { exchange } \\
\text { during } \\
\text { transitioning } \\
\text { from acute care } \\
\text { hospital to } \\
\text { rehabilitation } \\
\text { hospital. }\end{array}$ & $\begin{array}{l}\text { An exploratory } \\
\text { qualitative study } \\
\text { Data Collection: } \\
\text { Semi-structured } \\
\text { face to face } \\
\text { interviews and } \\
\text { observations. }\end{array}$ & 13 patients & $\begin{array}{l}2 \text { acute care } \\
\text { hospitals and } 1 \\
\text { rehabilitation } \\
\text { hospital. } \\
\text { Transition from } \\
\text { acute care hospital } \\
\text { to rehabilitation } \\
\text { hospital. }\end{array}$ & $\begin{array}{l}\text { Information exchange between provider and older patients had more } \\
\text { paternalistic nature instead of collaborative. } \\
\text { Older patients experienced difficulties in absorbing information at } \\
\text { transition points due to the pace and a number of the interactions } \\
\text { with different health care providers during transitions. } \\
\text { In spite of expectations, many patients had little to no information } \\
\text { about their transition plan including their medications. }\end{array}$ \\
\hline $\begin{array}{l}\text { McAiney, et al. } \\
(2017)^{58} \text {, } \\
\text { Canada }\end{array}$ & $\begin{array}{l}\text { Describing } \\
\text { intensive } \\
\text { geriatric service } \\
\text { workers' role } \\
\text { and influence of } \\
\text { this coaching } \\
\text { service on older } \\
\text { patients, } \\
\text { caregivers and } \\
\text { the broader } \\
\text { health system. }\end{array}$ & $\begin{array}{l}\text { A mixed method } \\
\text { study } \\
\text { Data Collection: } \\
\text { Interviews with } \\
\text { patients and } \\
\text { caregivers. } \\
\text { Chart audits, } \\
\text { monitoring } \\
\text { achievement of } \\
\text { care goals. }\end{array}$ & $\begin{array}{l}49 \text { patients } \\
\text { and } 25 \\
\text { caregivers. } 19 \\
\text { key } \\
\text { stakeholders }\end{array}$ & $\begin{array}{l}\text { Hospital } \\
\text { Transition across } \\
\text { continuum of care } \\
\text { from admission to } \\
\text { discharge. }\end{array}$ & $\begin{array}{l}\text { The intensive geriatric service worker facilitated the patient-provider } \\
\text { communication and increased older patients' adherence to } \\
\text { medication treatment. } \\
66.2 \% \text { of older patients were extremely satisfied with the intensive } \\
\text { geriatric service, while } 33.8 \% \text { was satisfied. }\end{array}$ \\
\hline
\end{tabular}




\begin{tabular}{|c|c|c|c|c|c|}
\hline $\begin{array}{l}\text { Bayliss, et al. } \\
(2016)^{59} \text {, USA }\end{array}$ & $\begin{array}{l}\text { Developing a } \\
\text { quality care } \\
\text { assessment } \\
\text { measure for } \\
\text { patient with } \\
\text { multiple chronic } \\
\text { conditions. }\end{array}$ & $\begin{array}{l}\text { Qualitative study } \\
\text { Data collection: } \\
\text { Focus groups } \\
\text { following } \\
\text { interactive webinar } \\
\text { based on Delphi } \\
\text { Method. }\end{array}$ & $\begin{array}{l}10 \text { patients } \\
\text { aged } 70-87 \\
\text { with three to } \\
\text { six chronic } \\
\text { conditions. } \\
17 \text { experts in } \\
\text { clinical } \\
\text { geriatrics and } \\
\text { multiple } \\
\text { chronic } \\
\text { condition } \\
\text { research, } \\
\text { health policy. }\end{array}$ & $\begin{array}{l}\text { Research } \\
\text { department within } \\
\text { an integrated } \\
\text { delivery system. }\end{array}$ & $\begin{array}{l}\text { Older patients reported optimized patient-clinician communication } \\
\text { and written communication of treatment plan as a measure for high- } \\
\text { quality multiple chronic condition care. } \\
\text { Older patients endorsed the use of electronic medical record for } \\
\text { information transfer between providers as an indicator of high-quality } \\
\text { multiple chronic condition care. }\end{array}$ \\
\hline $\begin{array}{l}\text { Eyler, et al. } \\
(2016)^{60}, \text { USA }\end{array}$ & $\begin{array}{l}\text { Evaluating the } \\
\text { impact of the } \\
\text { pharmacist-led } \\
\text { motivational } \\
\text { interviewing on } \\
\text { post-discharge } \\
\text { medication } \\
\text { adherence of } \\
\text { older patients } \\
\text { with } \\
\text { pneumonia. }\end{array}$ & $\begin{array}{l}\text { Prospective- } \\
\text { randomised control } \\
\text { study } \\
\text { Data Collection: } \\
\text { Controlled survey } \\
\text { and follow-up } \\
\text { phone interviews. }\end{array}$ & $\begin{array}{l}30 \text { patients; } \\
16 \\
\text { intervention } \\
14 \text { control }\end{array}$ & $\begin{array}{l}\text { Tertiary medical } \\
\text { centre. } \\
\text { Discharged from } \\
\text { medical centre to } \\
\text { long-term care } \\
\text { facilities, short term } \\
\text { rehabilitation or } \\
\text { nursing facilities. }\end{array}$ & $\begin{array}{l}\text { Pharmacist-led motivational interviewing had potential to increase } \\
\text { patient antibiotic adherence. } \\
\text { Antibiotic adherence rate was } 87 \% \text { in intervention vs } 64 \% \text { in control } \\
\text { group. } \\
\text { Older patients were every satisfied with pharmacist interactions } \\
\text { about their antibiotic regimens during discharge. }\end{array}$ \\
\hline $\begin{array}{l}\text { O'Kula, et al. } \\
(2016)^{61}, \text { USA }\end{array}$ & $\begin{array}{l}\text { Comparing care } \\
\text { transition } \\
\text { outcomes } \\
\text { between older } \\
\text { people with } \\
\text { English } \\
\text { speaking and } \\
\text { non-English } \\
\text { speaking } \\
\text { background. }\end{array}$ & $\begin{array}{l}\text { A controlled trial } \\
\text { Data Collection: } \\
\text { Post-discharge } \\
\text { interviews with } \\
\text { patients }\end{array}$ & $\begin{array}{l}117 \text { patients } \\
63 \text { English } \\
\text { Speaking } \\
16 \text { English- } \\
\text { Spanish } \\
\text { Bilingual }\end{array}$ & $\begin{array}{l}\text { A single tertiary care } \\
\text { centre. } \\
\text { Transitions between } \\
\text { acute and outpatient } \\
\text { care. }\end{array}$ & $\begin{array}{l}\text { Quality of care transitions communication was lower for older non- } \\
\text { English speaking, bilingual patients than only English-speaking } \\
\text { participants. Hospital readmission within } 30 \text { days of discharge } \\
\text { was lower in English-speaking older patients ( } 19 \% \text { vs } 13.6 \% \text {, } \\
\text { chi-square test =result not stated, } P=0.56) \text {. }\end{array}$ \\
\hline $\begin{array}{l}\text { Rustad, et al. } \\
(2016)^{62}, \\
\text { Sweden }\end{array}$ & $\begin{array}{l}\text { Exploring } \\
\text { experiences of } \\
\text { older patients } \\
\text { of }\end{array}$ & $\begin{array}{l}\text { A descriptive, } \\
\text { explorative } \\
\text { qualitative design. }\end{array}$ & 14 patients & $\begin{array}{l}\text { Local Hospital } \\
\text { Home-hospital- } \\
\text { home. }\end{array}$ & $\begin{array}{l}\text { Older patients found care transition as complex and challenging } \\
\text { process. }\end{array}$ \\
\hline
\end{tabular}


care transition Data Collection:
from hospital to Semi-structured

municipal

interviews.

health care

services.

Wong, et al.

(2016) ${ }^{63}$,

Canada

Examinin

patients'

experience of Data Collection:

hospital Interviews with

discharge from patients and focus

their

group.

perspectives.

$(2014)^{64}, \mathrm{~N}$

Zealand

Exploring the

older patients,

aged 75 and

over, manage

their

medication

changes at

home following

hospital

discharge.

Hvidt, et al. Investigating
(2014)

$\begin{array}{ll}(\mathbf{2 0 1 4})^{65}, & \text { the ability of } \\ \text { Denmark } & \text { older patients' }\end{array}$

to recall

discharge

instructions.

Lindquist, et al. Determining

$(2014)^{66}$, USA the ways of

older patients

dosing their

regular

medications in

the home.

Qualitative Study

Data collection

Semi-structured

interviews.

Quantitative

Descriptive

Data collection: A

cross-sectional

questionnaire

study with patients

discharged from a

university hospital.

Qualitative study

Data Collection:

Interviews with

patients.

Recording of

patients' home
Hospital

Discharge from the

hospital to home.

Half of the older patients were unaware of the details and reasons for medication changes.

Older patients were not willing to ask questions about their

medications.

Majority of older patients trusted the expertise of doctors; therefore, they accepted their decisions about medications without questioning them.

Some older patients were extremely confused about their

medications.

102 patients: Quick Diagnostic Unit

40 patients in in a university

older group hospital.

(Age $\geq 65$ ),

Discharge from

62 patients in hospital to home.

younger

200 seniors

Hospital.

medication
Patients recruited at

hospital, interviewed

at their homes.
Recall of correct medication information was higher in the younger patients compared with older patients (Odds ratio $4.20,95 \% \mathrm{Cl} 1.50$ 11.90, $\mathrm{P}=0.016$ ).

Older patients were less aware of their comprehensive deficits

compared to younger patients (Odds ratio $0.94,95 \% \mathrm{Cl} 0.90-0.98$. $\mathrm{P}=0.001$ ).

Unnecessary complexity of medication regimens was prominent problem among older people.

Misunderstanding medication instructions was one reasons behind medication regimen over-complexity.

Older people changed their lifestyle to accommodate the medication changes. 
regimen details

(name, dose and

frequency).

\begin{tabular}{|c|c|c|}
\hline $\begin{array}{l}\text { Blennerhassett, } \\
\text { et al. }(2011)^{67} \text {, } \\
\text { Australia }\end{array}$ & $\begin{array}{l}\text { Examining } \\
\text { management of } \\
\text { medications by } \\
\text { older people } \\
\text { with non- } \\
\text { English } \\
\text { speaking } \\
\text { background } \\
\text { after discharge. }\end{array}$ & $\begin{array}{l}\text { A qualitative study } \\
\text { Data Collection: } \\
\text { Interviews with } \\
\text { patients. Focus } \\
\text { group discussions } \\
\text { with hospital } \\
\text { clinicians, } \\
\text { pharmacist and } \\
\text { community nurses. }\end{array}$ \\
\hline $\begin{array}{l}\text { Knight, et al. } \\
(2011)^{68} \text {, UK }\end{array}$ & $\begin{array}{l}\text { Explore } \\
\text { experience of } \\
\text { older peoples } \\
\text { and their } \\
\text { careers at } \\
\text { discharge in } \\
\text { regard to } \\
\text { managing } \\
\text { medication and } \\
\text { organization. }\end{array}$ & $\begin{array}{l}\text { Qualitative Study } \\
\text { Data Collection: } \\
\text { Semi-structured } \\
\text { interviews. } \\
\text { Review of patient } \\
\text { medication diaries }\end{array}$ \\
\hline $\begin{array}{l}\text { Arora, et al. } \\
(2010)^{69}, \text { USA }\end{array}$ & $\begin{array}{l}\text { Reporting older } \\
\text { patients' post- } \\
\text { discharge } \\
\text { problems and } \\
\text { identifying } \\
\text { patients' } \\
\text { perceptions of } \\
\text { communication } \\
\text { between their } \\
\text { primary care } \\
\text { physicians and } \\
\text { hospital } \\
\text { physicians. }\end{array}$ & $\begin{array}{l}\text { Prospective mixed } \\
\text { methods study } \\
\text { Data collection: } \\
\text { Interviews with } \\
\text { older patients and } \\
\text { surveys with } \\
\text { primary care } \\
\text { physicians. }\end{array}$ \\
\hline
\end{tabular}

\section{8 patients \\ 12 ward \\ pharmacists \\ 8 community \\ nurses \\ Transfer from \\ hospital to the \\ community}

\section{7 patients and Hospital}

12 carers.

Discharge home

form hospitals.

Patients lacked knowledge about medication and changes. Interpreter Pervices were not used routinely.

For the older patients with non-English speaking background, there

was lack of available translated educational materials.

Medication changes and different brand names were contributors to

medication mismanagement in older patients.

Patients' satisfaction with the information provided about medication was varied.

Inadequate explanation about medication at discharge.

The communication between hospital and GPs and community pharmacists was poor.

40 Patients Single academic

medical centre

From admission to

discharge (nursing

home, rehabilitation

or homes)
Patients, whose primary physicians were not aware of

hospitalizations, were more likely to report post-discharge issues

including medication problems (67\% vs. $33 \%$, Fisher's exact test $=$

result not stated, $\mathrm{P}<0.05)$.

Older patients reported their confusion due to post-discharge

medication problems.

Primary care physicians' awareness of their patients' discharge and hospitalizations was important to follow up appointments and medications.

Patients' perception of good communication between primary care physicians and hospital physicians was far from the reality. 


\begin{tabular}{|c|c|c|c|c|c|}
\hline $\begin{array}{l}\text { Mesteig, et al. } \\
(2010)^{70}, \\
\text { Norway }\end{array}$ & $\begin{array}{l}\text { Describing } \\
\text { unwanted } \\
\text { adverse events } \\
\text { by the } \\
\text { ambulatory } \\
\text { team among } \\
\text { older patients } \\
\text { discharged from } \\
\text { a geriatric } \\
\text { evaluation and } \\
\text { management } \\
\text { unit (GEMU). }\end{array}$ & $\begin{array}{l}\text { A prospective } \\
\text { observational } \\
\text { study } \\
\text { Data Collection: } \\
\text { Collection of } \\
\text { baseline } \\
\text { characteristics } \\
\text { from hospital } \\
\text { record, } \\
\text { observations. }\end{array}$ & 118 patients & $\begin{array}{l}\text { 15-bed geriatric } \\
\text { evaluation and } \\
\text { management unit. } \\
\text { Discharged from the } \\
\text { GEMU to their } \\
\text { homes. }\end{array}$ & $\begin{array}{l}\text { Approximately } 60 \% \text { of frail elderly patients experienced unwanted } \\
\text { incidents during transition from hospital to home and following } 4 \\
\text { weeks. } \\
\text { Majority of unwanted effects were associated with information } \\
\text { exchange, medication regimens and disagreements between services. } \\
\text {. }\end{array}$ \\
\hline $\begin{array}{l}\text { Dedhia, et al. } \\
(2009)^{71}, \text { USA }\end{array}$ & $\begin{array}{l}\text { Testing the } \\
\text { feasibility and } \\
\text { effectiveness of } \\
\text { a discharge } \\
\text { planning and } \\
\text { quality } \\
\text { improvement } \\
\text { intervention on } \\
\text { care transitions } \\
\text { of older } \\
\text { patients. }\end{array}$ & $\begin{array}{l}\text { Quasi- } \\
\text { experimental pre- } \\
\text { post study design. } \\
\text { Data collection: } \\
\text { The data were } \\
\text { collected via } \\
\text { validated data } \\
\text { collection } \\
\text { instruments during } \\
\text { hospitalization, } \\
\text { within } 1 \text { week of } \\
\text { discharge, and } \\
\text { approximately } 30 \\
\text { days after } \\
\text { discharge. }\end{array}$ & $\begin{array}{l}238 \text { patients } \\
\text { for pre- } \\
\text { intervention } \\
\text { stage, } \\
185 \text { patients } \\
\text { for the post- } \\
\text { intervention } \\
\text { period. }\end{array}$ & $\begin{array}{l}\text { Three distinct } \\
\text { hospital types } \\
\text { including an } \\
\text { academic, } \\
\text { community-based } \\
\text { teaching hospital, } \\
\text { not-for-profit } \\
\text { community hospital. } \\
\text { Discharge from } \\
\text { general medicine } \\
\text { ward to home. }\end{array}$ & $\begin{array}{l}\text { Quality intervention including physician-pharmacist collaborative } \\
\text { medication reconciliation, scheduled discharge meeting, } \\
\text { multidisciplinary team collaboration, and providing patient with } \\
\text { simple medication instructions upon discharge admission resulted in } \\
\text { successful transition in older patients ( } 87 \% \text { vs } 78 \% \text {; OR }=2.33,95 \% \\
\mathrm{Cl}=1.34-4.05 \text { ) and reduced the readmission rates. ( } 14 \% \text { vs } 22 \% \text {; } \\
\mathrm{OR}=0.55,95 \% \mathrm{Cl}=0.32-0.94) \text {. }\end{array}$ \\
\hline $\begin{array}{l}\text { Del Sindaco, et } \\
\text { al. }(2007)^{72} \text {, } \\
\text { Italy }\end{array}$ & $\begin{array}{l}\text { Determining } \\
\text { influence of a } \\
\text { disease } \\
\text { management } \\
\text { program on } \\
\text { older } \\
\text { patients. } \\
\text { Program } \\
\text { included } \\
\text { discharge } \\
\text { planning, } \\
\text { therapy }\end{array}$ & $\begin{array}{l}\text { Randomised } \\
\text { Controlled Trial } \\
\text { Data Collection: } \\
\text { Review of } \\
\text { discharge \& visit } \\
\text { summary. } \\
\text { Medical record } \\
\text { review. Periodical } \\
\text { phone calls. } 2 \text { year } \\
\text { follow up patients' } \\
\text { outcomes. }\end{array}$ & $\begin{array}{l}173 \text { patients, } \\
86 \\
\text { Intervention } \\
\text { and } 87 \text { usual } \\
\text { care. }\end{array}$ & $\begin{array}{l}2 \text { hospital heart } \\
\text { failure clinics. } \\
\text { Hybrid Intervention: } \\
\text { combining hospital } \\
\text { clinic-based and } \\
\text { home-based care. }\end{array}$ & $\begin{array}{l}\text { Length of hospital stay was reduced ( } 9.5 \text { vs } 12.5 \text { days, t-test }=\text { result } \\
\text { not stated, } \mathrm{P}=0.0025) \text {. Mortality for heart failure }(24.4 \% \text { versus } 28.7 \% \text {, } \\
\text { relative risk reduction } 0.15,95 \% \mathrm{Cl}-0.39-0.48, \mathrm{P}>0.05) \text {. } \\
\text { Significant improvements seen in functional status, quality of life and } \\
\text { b-blocker prescription rate. } \\
\text { Readmission and death risks were reduced ( } 36 \% \text { vs } 26.2 \text { ). }\end{array}$ \\
\hline
\end{tabular}


optimisation,

improved

communication.

Flacker, et al. $(2007)^{73}$, USA

Examining olde patients' recal

communication of discharge instructions occurred

between

themselves and

hospital staff

before

discharge.

Spinewine, et
al. $(2007)^{74}$,

Evaluating the

influence of

pharmaceutical

care on

appropriatenes

of prescribing.

Randomised

controlled trial.

Data Collection:

Medical record

review and an

interview with

each patient or

career to identify

demographic

characteristics,

clinical status, and

medications.

Lopez Cabezas, Examining the A randomised,

et al. (2006) $)^{75}$,

Italy efficacy of prospective, open

educational clinical trial

intervention

conducted by a

pharmacist in

patients with

heart failure.
Data Collection:

Collection of

patients'

sociodemographic
269 patients 953-bed teaching

aged 70 years hospital

and older and

their families Transfer is from

were hospital to home.

interviewed.

203 patients Acute Geriatric

Evaluation and

Management ${ }^{20}$ unit

at tertiary hospital.

Admission to acute GEM unit, hospital

stay, discharge.

134 patients, Local hospital.

70 (52.2\%) Study conducted

intervention, during hospital stays, ratio $\mathrm{HR} 0.56,95 \% \mathrm{Cl} 0.32-0.97, \mathrm{P}<0.05$ ).

at point of discharge

control

and during patients'

follow up hospital

visits.
The patients received active education program had less re-

admissions than the patients in the control group (9 vs 26

readmissions after 2 months intervention (Cox's proportional hazard

Older patients who remembered receiving medication instructions

were more likely to adhere to taking their medications.

Wischarge instructions by hospital staff enabled patients to take more

role in their self-care after discharge.

$8.4 \%$ of older patients who recalled receiving discharge medications

作

stated that they did not take their medications correctly.

Pharmaceutical care reduced misuse, overuse, and unnecessary Pedication use in older patient.

Providing older patients with pharmaceutical care via written and oral meutic information at acute GEM unit improved appropriate in older patients during hospital stay and after

discharge. 


\begin{tabular}{|c|c|c|c|c|}
\hline $\begin{array}{l}\text { Shen, et al. } \\
(2006)^{76} \text {, } \\
\text { Australia }\end{array}$ & $\begin{array}{l}\text { Assessing the } \\
\text { impact of a } \\
\text { nurse-initiated } \\
\text { medication } \\
\text { education } \\
\text { program for } \\
\text { older patients } \\
\text { in terms of } \\
\text { increased } \\
\text { medication } \\
\text { knowledge and } \\
\text { adherence } \\
\text { following } \\
\text { discharge. }\end{array}$ & $\begin{array}{l}\text { Non-randomised } \\
\text { Control Study } \\
\text { Data Collection: } \\
\text { Interviews and } \\
\text { satisfaction survey. }\end{array}$ & 86 patients & $\begin{array}{l}\text { Teaching hospital. } \\
\text { Discharge from } \\
\text { hospital to home. }\end{array}$ \\
\hline $\begin{array}{l}\text { Enguidanos, et } \\
\text { al. }(2005)^{77} \text {, } \\
\text { USA }\end{array}$ & $\begin{array}{l}\text { Identifying } \\
\text { medication } \\
\text { documentation } \\
\text { issues at the } \\
\text { point of } \\
\text { discharge of } \\
\text { older patients. }\end{array}$ & $\begin{array}{l}\text { Quantitative } \\
\text { Descriptive study } \\
\text { design. } \\
\text { Data collection: } \\
\text { Surveys with } \\
\text { patients and } \\
\text { physicians. Review } \\
\text { of medication } \\
\text { charts. }\end{array}$ & $\begin{array}{l}\text { A random } \\
\text { sample of } 104 \\
\text { patients, } \\
50 \text { primary } \\
\text { care and } \\
\text { outpatient } \\
\text { physicians }\end{array}$ & $\begin{array}{l}\text { A large managed } \\
\text { care medical centre } \\
\text { At the discharge } \\
\text { point of the hospital }\end{array}$ \\
\hline $\begin{array}{l}\text { Coleman, et al. } \\
(2004)^{78} \text {, USA }\end{array}$ & $\begin{array}{l}\text { Testing whether } \\
\text { a patient- } \\
\text { centred } \\
\text { intervention } \\
\text { designed for } \\
\text { promotion } \\
\text { cross-site } \\
\text { communication } \\
\text { encouraged } \\
\text { older patients } \\
\text { to play a more } \\
\text { active role in }\end{array}$ & $\begin{array}{l}\text { Quasi- } \\
\text { experimental } \\
\text { design } \\
\text { Data collection: } \\
\text { The use of data } \\
\text { obtained from the } \\
\text { participating health } \\
\text { system's } \\
\text { administrative data } \\
\text { files. }\end{array}$ & $\begin{array}{l}158 \\
\text { Intervention } \\
\text { patients vs. } \\
1,235 \text { Control } \\
\text { patients form } \\
\text { health } \\
\text { delivery } \\
\text { system's } \\
\text { administrative } \\
\text { records. }\end{array}$ & $\begin{array}{l}\text { A large integrated } \\
\text { delivery system } \\
\text { Discharge from acute } \\
\text { care facility to home. }\end{array}$ \\
\hline
\end{tabular}

Nursing-staff-conducted medication education program improved older patients' medication knowledge.

$78 \%$ of patients expressed usefulness of education program.

Before education program, medication knowledge of older patients indicated that they knew 50\% of brand names, dosage and times, 55\% of purpose of medications, and $15 \%$ of major side effects. Relevant figures at follow-up home visits significantly increased to $90 \%, 85 \%$, and $25 \%$, respectively $(P .05)$
$89 \%$ of participated patients reported high levels of satisfaction with communication about discharge medications, however there was a discrepancy between discharge orders and older patients' medication reports in terms of the numbers of medications.

Of 104 chart reviews, $56 \%$ of medical charts had missing entries, mainly in the indication section and $23 \%$ had medical terminology.

Hospitalized patients who received interventions were almost half as likely to return to the hospital.

$75 \%$ of older patients who received interventions of medication-self

medications.

$87 \%$ of intervention patients understood the reason why they took each medication and $94 \%$ of them reported that they understood the route of each medication. 


\begin{tabular}{|c|c|c|c|c|c|}
\hline $\begin{array}{l}\text { Sexton, et al. } \\
(1999)^{79}, \text { UK }\end{array}$ & $\begin{array}{l}\text { Investigating } \\
\text { the accuracy of }\end{array}$ & Qualitative Study & 56 patients & General hospital. & $\begin{array}{l}\text { Historic poor standards of seamless pharmaceutical care and record } \\
\text { keeping by health care professionals. }\end{array}$ \\
\hline & $\begin{array}{l}\text { documentation } \\
\text { of medication- } \\
\text { information on } \\
\text { discharge and } \\
\text { the } \\
\text { communication } \\
\text { methods } \\
\text { used. }\end{array}$ & $\begin{array}{l}\text { Data Collection: } \\
\text { Medical record } \\
\text { review. } \\
\text { Interview with } \\
\text { patients. } \\
\text { Surveys with GPs. }\end{array}$ & & $\begin{array}{l}\text { Discharges home } \\
\text { from the acute } \\
\text { geriatric unit. }\end{array}$ & $\begin{array}{l}\text { Medication inadequacies were one of the biggest issues for older } \\
\text { patients. } \\
57 \% \text { of patients had medication related problems after discharge. }\end{array}$ \\
\hline $\begin{array}{l}\text { Clare, et al. } \\
(1998)^{80}, \\
\text { Australia }\end{array}$ & $\begin{array}{l}\text { Identifying } \\
\text { satisfaction } \\
\text { with discharge } \\
\text { planning } \\
\text { identified by } \\
\text { older patients, } \\
\text { caregivers, } \\
\text { health } \\
\text { professionals } \\
\text { and identifying } \\
\text { older patients' } \\
\text { and carers' } \\
\text { knowledge of } \\
\text { medications } \\
\text { and recovery } \\
\text { needs. }\end{array}$ & $\begin{array}{l}\text { A mixed method } \\
\text { study } \\
\text { Data Collection: } \\
\text { Interviews and } \\
\text { questionnaire }\end{array}$ & 67 patients & $\begin{array}{l}\text { Hospital } \\
\text { Transfer form } \\
\text { hospital to nursing } \\
\text { service }\end{array}$ & $\begin{array}{l}71 \% \text { of elderly expressed their satisfaction with their discharge as } \\
\text { they felt involved in decision-making process in discharge plan. } \\
91 \% \text { of older patients reported daily medication intake. Of those } \\
\text { patients, only } 52 \% \text { patients received written information. }\end{array}$ \\
\hline $\begin{array}{l}\text { Leduc, et al. } \\
(1998)^{81} \\
\text { Canada }\end{array}$ & $\begin{array}{l}\text { Examining the } \\
\text { extent to which } \\
\text { older patients } \\
\text { discharged to } \\
\text { the community } \\
\text { from an acute- } \\
\text { care hospital } \\
\text { used the } \\
\text { healthcare }\end{array}$ & $\begin{array}{l}\text { Quantitative } \\
\text { Descriptive } \\
\text { Analysis } \\
\text { Data Collection: } \\
\text { Interviews, } \\
\text { Chart reviews }\end{array}$ & 212 patients & $\begin{array}{l}\text { A general and } \\
\text { teaching hospital } \\
\text { Discharge from acute } \\
\text { geriatric ward to } \\
\text { community }\end{array}$ & $\begin{array}{l}\text { Communication and coordination between community and hospital } \\
\text { increased older patient adherence to prescribed services two times. }\end{array}$ \\
\hline
\end{tabular}

thcare 
Rich, et al.

$(1996)^{82}$, USA

assessing

medication

compliance of

older patients

with congestiv

heart failure

after

intervention of

patient

education.

Burns, et al.

$(1992)^{83}$, UK

Evaluating the

effects of

communication

between

hospital and

general

practitioners

about

medication

therapy of older

patients.

Cochrane, et al. To ascertain

(1992) ${ }^{84}$ UK

changes in drug

treatment of

elderly patients

after discharge

from hospital

and to

determine

areas of

communication

which may
156 patients; Tertiary hospital

80

Data Collection:

Collection of the

number of

medications at the

discharge.

Prospective CrossSectional Study

Data Collection:

Home visits; post-

discharge drug

therapy was

assessed the ones

that were

prescribed during

discharge.

Quantitative study

Data collection:

Structured verbal

questionnaire. intervention,

76 control

At the time of

discharge and post-

discharge period

\section{Patient Hospital}

Discharged form

Geriatric Unit to

home or nursing

home

\section{0 patients A district health}

discharged authority

from five

geriatric

wards.

Discharge from

geriatric ward to

Compliance rates in intervention was remarkably high, achieved by

$85 \%$ in intervention vs $69.7 \%$ in the control group.

Readmissions per patient were decreased by $32 \%$, the length of

hospital stay was reduced by $31 \%$.

home.

$27 \%$ of patients had new medications issued after discharge.

There was lack of continuity of medication in older patients.

There was a need for close communication and collaboration

between hospital and community care professionals to prevent

medication mistakes in older patients.

Older patients were not communicated with about their medication changes during their hospital stay.

The lack of continuity was identified in older patients' medications

between the ones provided on discharge and the ones taken by

patients during post-discharge period. 
need

improvement.

$(1982)^{85}$, USA
Investigating

whether

communicating

with older

patients about

drug regimen at

discharge leads

to increased

patient

knowledge at

the post-

discharge

period and

comparing the

improvement of

medication

knowledge by

age groups.
Quantitative

descriptive study

Data collection:

Structured phone

survey with

discharged

patients. Review of

patients' drug

regimens from

medical records.
545 patients

Hospital

Discharge from

hospital to home.
Adherence to prescribed medications was found higher in older (age $\geq 65$ ) than the younger patients (Age<65) 
Two investigators were involved with synthesizing the themes and subthemes from the papers. Regular discussions were conducted with the other investigators, which enabling agreement on the nature and content of themes and subthemes. A six-step thematic analysis approach was used ${ }^{86}$. The first step involved familiarisation of qualitative data, where extracted data from the results sections of studies were read and reread to search for meanings and patterns. Initial ideas were noted to develop comprehensive understandings of the content. The second step related to generation of initial codes. Preliminary codes were developed, which identified relevant features of the data across the whole data set. The third step involved searching for themes, where different codes were sorted into potential themes. All data relevant to each potential theme were gathered. The fourth step included reviewing themes to determine which ones were to be combined, separated, refined or discarded. A thematic map was created at this step. In the fifth step, themes and subthemes were defined and named. The sixth step involved generation of the findings, where concise names and definitions for each theme were produced. Key findings of included studies were incorporated into identified themes, and examples from studies were used to illustrate the themes generated.

Findings from quantitative studies were reworded as textual information, which was read and reread to determine how it could be incorporated into themes and subthemes obtained from qualitative studies. This textual information was aggregated with qualitative findings using descriptive synthesis. Mixed methods studies were analysed using the approaches already explained for qualitative and quantitative data respectively. Findings from quantitative and mixed method studies were analysed following the six-step process. MMAT results of studies were checked simultaneously while conducting the six-step thematic analysis to identify any methodological deficiencies.

A total of 33 studies were included in this review. The earliest identified study was published in 1979. There was only one study published between 1980 and 1990. Six studies were published from 1990 to 2000. While 10 studies were published out between 2000 and 2010, 16 studies were published from 2010 to 2019. The total sample size of older patients included in studies was 4525 patients. For qualitative studies, sample sizes ranged from 7 to 200 patients while for quantitative studies, sample sizes ranged from 30 to 744 patients. For mixed methods studies, sample sizes ranged from 47 to 60 patients. Twenty-eight studies were 
conducted in acute care hospital settings, 5 were undertaken at subacute settings, and only one study was conducted at residential aged care facility. Most studies were conducted in either the United States (10) or the United Kingdom (5). There were 12 qualitative studies, comprising 8 semi-structured interviews studies, one narrative interviewing study, 2 observational studies and three focus group studies. Most interview studies were conducted with older patients at acute hospital settings. Of these studies, only 2 studies adopted the concept of data triangulation combining interviews with focus group discussions ${ }^{63}$ or observations ${ }^{57}$. Seventeen studies were quantitative in design, including 4 survey studies, 2 retrospective audit reviews, 5 randomised controlled trials, one structured verbal questionnaire study, 2 quasi-experimental studies, and 4 non-randomised controlled studies. Controlled trials were conducted in different countries including USA, Belgium, Australia, Italy and Hong Kong and most of them were undertaken at acute care hospital settings ${ }^{60,61,74-76,82}$. There were also 4 mixed methods studies.

180 Of these, 2 studies used a combination of surveys and interviews. One study combined chart audits and interviews, whereas the other study integrated observational data with quantitative findings.

There were 4 major themes identified: links between communication and medication discrepancies; engagement with older patients to enable self-care; older patients' experiences with health professionals about their medication regimen; and strategies for communication about medications with older patients. Themes and subthemes with examples of representative quotes by older patients are shown in Table 2. A thematic map comprising the themes and subthemes is shown in Table 3.

Medication discrepancies that resulted from communication breakdowns between hospital and community settings were an ongoing problem that were addressed by older patients receiving simple, written and verbal medication information before discharge. Patients' attitudes towards their involvement in self-medication management and their ability 193 to make decisions about their medications were identified mostly in interview studies undertaken at acute hospital settings. Older patients' values about patient-provider relationships and trust in providers' knowledge influenced the degree of their involvement. Survey and interview studies reported that patient satisfaction with the amount and quality of information received before discharge was closely associated with patients’ post-discharge medication adherence. Only two studies conducted in Australia (an interview study) and USA

199 (an intervention study) addressed the relationship between quality of communication and 200 language barriers of patients ${ }^{61,67}$. The interview study conducted with older patients from three different non-English language backgrounds revealed detailed knowledge about medication 
202 mismanagement experienced after discharge ${ }^{67}$. Intervention studies conducted with different 203 professional groups such as nurses, physicians and pharmacists showed that medication 204 education provided to older patient at hospital settings improved medication knowledge and 205 medication management after discharge and also reduced medication-related readmissions ${ }^{54}$, $206 \quad 71,72,76$. 
Table 2 Themes, Subthemes \& Representative Quotes

\section{THEMES AND SUBTHEMES}

1. MEDICATION DISCREPANCIES ARE LINKED TO COMMUNICATION

- MEDICATION COMMUNICATION BETWEEN HOSPITALS AND THE COMMUNITY

- tallored COMMUNiCATION TO FACILITATE OLDER PATIENTS' UNDERSTANDING

- ACCURACY OF MEDICATION DOCUMENTATION

\section{ENABLING SELF-CARE THROUGH OLDER} PATIENT ENGAGEMENT

- PATIENT SELF-MANAGEMENT OF MEDICATIONS

- INVOLVEMENT WITH OLDER PATIENTS IN DECISION MAKING

\section{REPRESENTATIVE QUOTE EXAMPLES BY PATIENTS}

"When I usually have lab work done I have prescription signed.. maybe they changed the way of doing it. Now the pharmacy called me. But I'm supposed to have a note or something'”Arora (2010, p. 388)

"I wouldn't have taken it in any way. You really do only sort of half listen because it seems, you know, it seems that you don't know the language.” Bagge (2014, p. 794)

"Well they say very little, they just say you're on this and this and this, do you understand and they're keen to get off' 'Knight (2011, p. 286)

"I had problems getting my medications because they tell me that the medication was so high, but anyway, I didn't get some of my medications." Arora (2010, p. 388)

"Major category was those who had problems getting medication or therapy. For example, 'one of (the patients) treatment meds...was very hard to find and it delayed us giving her her meds. ” Arora (2010, p. 387)

"... well they do give you a thing from the hospital to give to your doctor just saying you're home and then on that, with that should be all the drugs. So then you've got to make sure that the surgery puts the drugs onto the record...it's even more daunting and then I mean you have to juggle with the chemist and the repeat prescriptions and goodness knows what" Knight (2011, p. 286)

"I needed a copy of his discharge papers from the hospital for insurance purposes..They didn't give me a discharge paper.” Arora (2010 p. 388)

"I think the take-home message is get [discharge instructions] written down. Because I didn't know all this; I'm guessing he took out the information and read it. So anything that's written is super useful." Wong (2016, p.100)

"You don't have any decision in your own healthcare at all. I think that's terrible!" Arora (2010 p. 389)

"Patient said she did not really have an opportunity to talk to the hospital staff about her medicine changes but she was not concerned by that because she would not have known what to discuss with them." Bagge (2014, p. 794)

"I've been receiving a new kind of tablet since I was in hospital. I don't know if it is because of directions from the hospital, I just take them and keep quiet.” Rustad (2016, p.774)

"I think that because I would ask if I had to, if I wasn't happy, I would take it upon myself to ask. I think you have to be prepared to do that. I mean I would, but not everybody would. I mean I work with the doctors" Knight (2011, p. 286) 
3. OLDER PATIENTS' EXPERIENCES WITH HEALTH PROFESSIONALS ABOUT THEIR MEDICATION REGIMEN

- OLDER PATIENTS' SATISFACTION WITH MEDICATION RELATED SERVICES

- INFORMATION EXCHANGE ABOUT MEDICATIONS

- $\quad$ EFFECTS OF PATIENT DEMOGRAPHIC CHARACTERISTICS ON PATIENT EXPERIENCES
"I think to myself 'they know what they're doing,' and just leave it to them, that's what I'm here for." Bagge (2014, p. 796).

"Because he is a specialist advising, I'm taking their advice, I'm not going to argue with them about it." Bagge (2014, p. 795)

"I wouldn't even [know] how to say 'why am I taking these pills?', because I might be disregarding their, you know, position, or something. No, I just do as I'm told."Bagge (2014, p. 795).

"They only answered the questions I put to them.", " a change in my symptoms were not adequately explained" Clare (1998, p.11)

"You don't know what the hell to do, do you? 'Sadly, this patient added, 'I was quietly confident of all my medication before, but since coming out of hospital I'm totally lost” Knight (2011, p. 288)

"I've carried on with the insulin dose that my specialist prescribed, not what the hospital prescribed. I didn 't see the specialist while I was in hospital as he was away." Blennerhassett (2011, p.34)

"One patient took three different opioids and crushed morphine sulfate slow-release tablets because, I thought I could see the tablet whole in my stool” Blennerhassett (2011, p.34).

"She's really helped me to make sure I take my medications and vitamins and that I eat the amountthat I'm supposed to. That has really helped me a lot. I've got more energy and feel much better than I did last winter." McAiney (2017, p.157)

"If they'd have given me a ton of them [medicines], I would still have taken them because they know better than I do" Bagge (2014, p. 794)

"I'm sure [the pharmacist] explained [the medications] to me, but... I remember nothing..." Wong (2016, p.100) 
4. STRATEGIES IN COMMUNICATING ABOUT MEDICATIONS WITH OLDER PATIENTS

- INDIVIDUALISED DISCHARGE SUMMARIES

- PHARMACISTS' INTERVENTIONS AND RECOMMENDATIONS ON MEDICATION APPROPRIATENESS

- IMPROVING MEDICATION KNOWLEDGE IN OLDER PATIENTS THROUGH MEDICATION EDUCATION
"When we saw our GP yesterday, she described in great detail exactly the significance and the severity of a bug in the blood if it was coming from the bladder. So, we got more out or our GP in 5 minutes than we got out of the doctors in the hospital in 8 days" Allen (2018, p.523)

"All participants valued medication education from the ward and community pharmacists including education regarding dose administration containers, explanation of discharge medication regimes and consideration of unwanted side- effects" Allen (2018, p.523) 
Twenty studies addressed the theme of medication discrepancies being linked to communication 55-57, 59, 61-64, 67-70, 77-81, 83-85. There were 3 subthemes relating to this theme: communicating about medication between hospital and the community, tailored communication to facilitate older patients' understanding, and accuracy of medication documentation.

Timely and appropriate communication about medications between the hospital and the community was a key factor in preventing medication discrepancies. Communication breakdowns occurred at the time of discharge from hospital to the community or in the early post-discharge period (from 5 to 30 days after discharge) 55, 56, 63, 67, 69-71, 79, 83, 84, 87. Older patients reported having difficulties in understanding medication changes after discharge 63, 64, 68, 69 . In a qualitative study of changed medication regimens, most older patients had continued taking discontinued medications after returning home due to lack of communication at the time of discharge ${ }^{84}$.

Patients described experiencing medication discrepancies including wrong frequency, incorrect time, dosage or missed prescription regime following discharge from hospital because of poor communication and lack of clear and adequate information about their medications ${ }^{68}$, ${ }^{70}$. In some quantitative studies, interventions that focused on communication with patients, primary care physicians (PCPs) and community pharmacists after patients' discharge improved the discharge experience and enabled patients to manage their medications properly at home, leading to reduced medication-related hospitalisation rates ${ }^{56,78}$.

Older patients expected that communication should occur between primary care physicians and inpatient physicians ${ }^{69}$. Likewise, older patients who frequently visited different PCPs reported that the PCPs lacked knowledge about their discharge medication changes. PCPs sometimes continued hospital-ceased medications or discontinued newly-prescribed hospital medications ${ }^{67}$. Older patients stated that they expected effective and prompt communication between health professionals located in primary and secondary care settings comprising hospital providers, their PCPs and community pharmacists ${ }^{68}$. They also expected that hospital pharmacists would provide them with a concise and clear list of prescribed medications and explanations about their purpose ${ }^{55,68}$.

Patients' understanding of medication information was enhanced through tailored communication that considered older patients' physical, cognitive, and emotional states and 
and clearly written instructions of their current treatment plan and provision of discharge summaries. In a qualitative study, older patients with multiple chronic conditions reported wanting timely and tailored communication ${ }^{59}$. Patients found it useful to receive written instructions about medication before discharge ${ }^{80}$. Older patients believed their knowledge could be improved by health professionals providing them with plain-language discharge summaries. They also reported the need for health professionals' awareness of their mental state when providing information about new medications as patients may not remember discharge explanations ${ }^{63}$. When older patients experienced close and ongoing communication with health professionals, they were more likely to correctly identify the purpose of their medications and to adhere to their medication regimens ${ }^{85}$.

Older patients reported lack of accuracy, completeness and clarity of medication documentation. This resulted in unwanted medication incidents, confusion about medication information, and concerns about medication changes, particularly when they were discharged from hospital to the community. Mesteig, et al. $(2010)^{70}$ reported that almost $60 \%$ of frail, older patients experienced unwanted medication incidents during their transition to home and within the first month after discharge. While $32 \%$ of the most common, unwanted incidents were caused by mistakes made during medication administration, $25 \%$ of incidents related to poor information exchange between a geriatric evaluation and management unit and primary health care staff. Older patients found the care transition from hospital to a community care setting to be a challenging and complex experience, since they were unsure or unaware of what medication information was sent by the hospital, and what had been received by the community care setting ${ }^{62}$. In another study, patients stated that they were not satisfied with the information they received at discharge, with only $40 \%$ reporting that the information was easy to comprehend ${ }^{77}$. Discharge summaries were hard to understand because of extensive use of medical abbreviations and jargon. Patient concern about the lack of clarity about changes made to their medications increased their reliance on family members ${ }^{64}$.

\section{Theme 2. Enabling self-care through older patient engagement}

Eleven studies identified the theme of enabling self-care through older patient engagement 53, 57, 58, 62, 64, 67-69, 73, 78, 80. There were 2 subthemes for this theme: patient selfmanagement of medications, and involvement with older patients in decision making.

Older patients viewed caring relationships with health professionals, and appropriate communication of medication information as key components of self-care management. Having information about the reasons why and how medications were to be taken was 
valued caring relationships with health professionals in their care transitions because such relationships supported their self-confidence in being independent at home. In contrast, negative experiences resulted from health professionals' failure to listen to patients' concerns at discharge and from health professionals making decisions about discharge medications without understanding what medications were prescribed by doctors outside the hospital ${ }^{53}$.

Some older patients reported no concerns with resuming their previous medicationtaking routines after discharge, whereas others expressed concerns about being able to adopt new routines after medication changes ${ }^{64,67}$. Patients identified strategies that helped them to obtain more information themselves at discharge, including taking responsibility to communicate with health professionals about preparing self-generated medication lists ${ }^{62,68}$. McAiney, et al. (2017) ${ }^{58}$ described a new health provider role - intensive geriatric service workers - who were community support providers addressing communication gaps and promoting effective self-management for older patients discharged to the community from acute care. Patients who received support from these workers demonstrated improved selfmanagement in adhering to treatment recommendations.

There were conflicting findings in regard to older patients' participation in decision making with medication-related communication. Patients were sometimes reluctant to ask questions about their medications during their hospital stay and were concerned about not knowing what to ask in relation to their medication changes ${ }^{64}$. Similarly, some patients did not wish to be engaged in discussions with health professionals as they believed that the health care team members knew what they were doing ${ }^{57}$. In contrast, some patients reported that interventions including home visits from transition coaches, follow-up visits by physicians and follow-up phone-calls enabled them to take a more active role in their own care across settings, which increased their understanding of medication regimens and enhanced their confidence in self-management. They reported that active participation increased their understanding of how to take their medications and recognise side effects ${ }^{78}$. In regard to self-care learning, some patients were more engaged in asking questions of nurses when they gave insulin injections, whereas others preferred consulting with their PCPs after discharge to learn the reasons for insulin changes, and monitoring and interpreting blood glucose levels ${ }^{53}$.

Theme 3. Older patients' experiences with health professionals about their medication regimen

Eighteen studies addressed the theme of older patients' experiences in communicating with health professionals about their medication regimen 53, 55, 57-59, 61, 63, 64, 66-69, 75-77, 80, 81, 85.

303 There were 3 subthemes for this theme: older patients' satisfaction with medication-related 
services, information exchange about medications, and the effects of patient demographic characteristics on patients' experiences of communication.

Older patients' satisfaction with medication-related services influenced their adherence to their medication regimen. Patients who received information about their medication therapy through active telephone follow-up and home visits after discharge reported higher satisfaction with the care received, and showed greater adherence with prescribed medications compared to patients who did not receive information on medications and follow-up phone calls ${ }^{75}$. Older patients were highly satisfied with the existence of a service addressing challenges during their movements across transitions of care since it promoted self-management, independence and medication adherence ${ }^{58}$.

Effective information exchange about medication regimens was viewed as an essential requirement by older patients. Older patients felt disappointed if they received inadequate explanation about discharge medications, particularly if their medications were changed ${ }^{55}$. In addition, not knowing the purpose of a medication and not receiving a written guide about discharge medications made patients feel vulnerable and helpless ${ }^{68}$. A survey of 67 older patients revealed they valued receiving instructions and discussing their medications with their doctors; however, only 52\% received written information and 46\% said no discussion occurred ${ }^{80}$. Similarly, in an interview study conducted with 40 older patients, 29 patients stated health professionals did not talk to them about medication changes before discharge. Similarly, a study involving interviews and observations demonstrated older patients' dissatisfaction with receiving "tidbits of information" to "no information" or "leaving without a follow-up plan" when they were being transferred ${ }^{57}$. Some patients attributed this situation to the busyness of physicians ${ }^{64}$ and busyness of health professionals of various disciplines during the patients' discharge period ${ }^{80}$.

Patients' demographic characteristics were associated with their communication experiences about their medication regimens ${ }^{57,65,66}$. A cross-sectional questionnaire study of hospitalised patients $(\mathrm{N}=102)$ showed that compared with younger patients ( $<65$ years old), older patients reported more difficulties in remembering correct medication instructions (78\% versus $54.3 \%$, respectively) ( $\mathrm{P}=0.02)$, which led to the need for different communication strategies with older patients before discharge ${ }^{65}$. An interview study and a controlled trial reported the effects of language barriers on patients' medication experiences ${ }^{61,67}$. Patients from non-English speaking backgrounds expressed more difficulties in taking new medications after being discharged. Some patients were confused by brand names. Similarly, older patients who 
had language barriers reported poorer communication in comparison with English-speaking patients ${ }^{61}$. Along with language problems, some patients said they needed opportunities to ask questions of health professionals to clarify concerns caused by hearing loss or slurring of speech ${ }^{80}$.

\section{Theme 4. Communication strategies to enable older patients' medication}

\section{knowledge}

Thirteen studies addressed the theme of communication strategies to enable older patients' medication knowledge 53, 54, 56, 60, 63, 67, 71, 72, 74, 76, 80, 82, 85. There were three subthemes for this theme: individualised discharge summaries, pharmacists' interventions and improvements in older patients’ medication knowledge through medication education.

Individualised discharge summaries involved medication instructions in simple language and clear information about follow-up care for older patients. Older patients emphasised the need to be given medication instructions written in plain language ${ }^{63,71}$. They believed having clearly written plain language discharge summaries enabled better management of their condition ${ }^{63}$. They also valued information from the ward pharmacist about the purpose and the nature of their discharge medication ${ }^{53}$. Patients stated that they valued clarification and information from PCPs about their discharge summaries and appreciated having their questions answered ${ }^{53}$. In one discharge planning intervention, older patients were given written discharge instructions including medication information with larger-than-normal font type and using simple language. Information was presented with straightforward explanations about how, when and why to take medications along with contact information of hospital health professionals in the event that patients had additional inquiries after discharge. Implementation of the intervention contributed to the reduction of older patients' readmission rates (14\% in the intervention group vs $22 \%$ in the control group, $\mathrm{OR}=0.55,95 \%, \mathrm{CI}=0.32-0.94$ ) and improved quality of transition from hospital to home, with a higher proportion of patients feeling better as a result of hospitalisation and a greater number of patients having successful transitions to home ${ }^{71}$.

Pharmacist interventions improved outcomes for older patients. Older patients believed that recommendations made by pharmacists on admission and at discharge were useful in decreasing unintended medication discrepancies caused by improper dosages or omissions of medications, and also reduced inappropriate prescriptions ${ }^{54}$. In an interview study, older patients identified useful strategies for improving outcomes, which included providing verbal and written information for medications, liaising with the community pharmacists for dose administration aids, and checking understanding about brand and generic name differences ${ }^{67}$. 
371 Additionally, older patients from non-English speaking backgrounds suggested that 372 community pharmacists who spoke their language were helpful in enabling them to better 373 manage their medications. In an intervention study, an Integrated Medicine Management 374 Service program was introduced as a solution to reduce medication-related readmissions 375 through direct patient consultations, and follow-up discussions with patients' community 376 pharmacists and PCPs ${ }^{56}$.

377 Medication education by health professionals was related to improvements in older 378 patients' medication knowledge. Older patients valued medication education from both 379 community and hospital pharmacists and their PCPs, particularly education about dose 380 administration aids, discharge medication regimens and unwanted side effects. Patients with 381 diabetes highlighted the importance of education and recommendations from their PCPs about 382 how to monitor and interpret blood glucose levels after discharge ${ }^{53}$. A prospective cohort study 383 showed that $98 \%$ of older patients were satisfied with a pharmacist-led program, which was 384 associated with a significant reduction in inappropriate medication use and medication-related 385 problems via medication reviews, reconciliation and counselling on admission and discharge $386 \quad 54$. An educational program consisting of hospital and primary care providers' collaboration 387 with older patients with heart failure was effective in reducing deaths, hospital readmission 388 rates and length of hospital stay. This program focused on physicians providing follow up 389 telephone calls with patients about their medication regiment and home visits. ${ }^{72}$. After 390 implementation of a nursing-initiated medication education program for older patients aimed 391 at improving medication knowledge prior to discharge, $78 \%$ of patients felt satisfied with the 392 program as it helped them to recall medication details such as names, dosages or times of 393 administration ${ }^{76}$. 
Table 3 Thematic Map for Included Studies

\begin{tabular}{|c|c|c|c|c|c|c|c|c|c|c|c|}
\hline \multirow[b]{2}{*}{$\begin{array}{c}\text { Study } \\
\text { (first author/ } \\
\text { Year/Country) }\end{array}$} & \multicolumn{3}{|c|}{$\begin{array}{c}\text { Medication discrepancies are linked to } \\
\text { communication }\end{array}$} & \multicolumn{2}{|c|}{$\begin{array}{c}\text { Enabling self-care through } \\
\text { older patient engagement }\end{array}$} & \multicolumn{3}{|c|}{$\begin{array}{c}\text { Older patients' experiences with health } \\
\text { professionals about their medication regimen }\end{array}$} & \multicolumn{3}{|c|}{$\begin{array}{l}\text { Strategies in communicating about } \\
\text { medications with older patients }\end{array}$} \\
\hline & $\begin{array}{l}\text { Communicati } \\
\text { on between } \\
\text { hospitals and } \\
\text { the } \\
\text { community }\end{array}$ & $\begin{array}{l}\text { Tailored } \\
\text { communi- } \\
\text { cation }\end{array}$ & $\begin{array}{l}\text { Accuracy of } \\
\text { medication } \\
\text { documentation }\end{array}$ & $\begin{array}{l}\text { Patient self- } \\
\text { management } \\
\text { of } \\
\text { medications }\end{array}$ & $\begin{array}{l}\text { Decision- } \\
\text { making } \\
\text { involvement } \\
\text { with older } \\
\text { patients }\end{array}$ & $\begin{array}{l}\text { Satisfaction } \\
\text { with } \\
\text { medication } \\
\text { related } \\
\text { services }\end{array}$ & $\begin{array}{l}\text { Information } \\
\text { exchange } \\
\text { about } \\
\text { medications }\end{array}$ & $\begin{array}{l}\text { Effects of } \\
\text { patient } \\
\text { demographic } \\
\text { characteristics }\end{array}$ & $\begin{array}{l}\text { Individualis } \\
\text { ed discharge } \\
\text { summaries }\end{array}$ & $\begin{array}{l}\text { Pharmacists' } \\
\text { interventions }\end{array}$ & $\begin{array}{l}\text { Medication } \\
\text { education }\end{array}$ \\
\hline Allen et al., 2018, Australia & & & & * & * & * & * & & * & & * \\
\hline $\begin{array}{l}\text { Arora et al. (2010), United } \\
\text { States }\end{array}$ & * & & & * & * & & & & & & \\
\hline $\begin{array}{l}\text { Bagge et al. (2014), New } \\
\text { Zealand }\end{array}$ & & & * & & * & & * & & & & \\
\hline Bayliss, et al. (2016), USA & & $*$ & * & & & $*$ & & & & & \\
\hline Cochrane et al. (1992), UK & * & & & & & & * & & & & * \\
\hline Coleman et al. (2004), USA & & & & * & * & & * & & & & * \\
\hline Dedhia et al., (2009), USA & * & & & & & & & & * & & \\
\hline $\begin{array}{l}\text { Enguidanos et al., (2005), } \\
\text { USA }\end{array}$ & & & * & & & & * & & & & \\
\hline Flacker et al. (2007), USA & & & & * & & & * & & & & \\
\hline German et al. (1982), USA & & * & & & & & * & & & & * \\
\hline $\begin{array}{l}\text { Hvidt et al. (2014), } \\
\text { Denmark }\end{array}$ & & & & & & & & * & & & \\
\hline Jeffs et al. (2017), Canada & & & & & * & & * & * & & & \\
\hline $\begin{array}{l}\text { Lindquist et al. (2014), } \\
\text { USA }\end{array}$ & & & & & & & * & * & & & \\
\hline López et al. (2006), Italy & & & & & & $*$ & & & & * & * \\
\hline $\begin{array}{l}\text { McAiney et al. (2017), } \\
\text { Canada }\end{array}$ & & & & * & & * & & & & & \\
\hline $\begin{array}{l}\text { Mesteig et al. (2010), } \\
\text { Norway }\end{array}$ & * & & & & & & * & & & & \\
\hline
\end{tabular}




\begin{tabular}{|c|c|c|c|c|c|c|c|c|c|c|c|}
\hline $\begin{array}{l}\text { Rustad et al. (2016), } \\
\text { Sweden }\end{array}$ & & & & * & * & & * & & & & \\
\hline $\begin{array}{l}\text { Shen et al. (2006), } \\
\text { Australia }\end{array}$ & & & & & & * & & & & & * \\
\hline $\begin{array}{l}\text { Spinewine et al (2007), } \\
\text { Belgium }\end{array}$ & & & & & & & * & & & * & * \\
\hline Wong et al. (2016), Canada & * & * & * & & & & & & * & & \\
\hline O’Kula et al. (2016), USA & & & & & & & & $*$ & & & \\
\hline Leduc et al. (1998), Canada & * & & & & & * & & & & & \\
\hline $\begin{array}{l}\text { Clare et al. (1998), } \\
\text { Australia }\end{array}$ & & * & & & & * & * & & & & \\
\hline Rich et al. (1996), USA & & & & & & & & & & & * \\
\hline $\begin{array}{l}\text { Burns et al. (1992), } \\
\text { Scotland }\end{array}$ & * & & & & & & & & & * & * \\
\hline Barnett et al. (2017), UK & * & & & & & & * & & & $*$ & * \\
\hline $\begin{array}{l}\text { Blennerhassett et al. } \\
\text { (2011), Australia }\end{array}$ & * & & & * & & & * & & & & * \\
\hline Eyler et al. (2016), USA & & & & & & * & & & & * & \\
\hline $\begin{array}{l}\text { Chiu et al. (2018), Hong } \\
\text { Kong }\end{array}$ & & & & & & * & * & & & $*$ & $*$ \\
\hline Sexton et al. (1999), UK & $*$ & & $*$ & & & & * & & & & \\
\hline Knight et al. (2011), UK & * & & * & * & * & * & * & & & & \\
\hline Gadbois et al. (2018), USA & * & & * & & & & * & & & & \\
\hline Sindaco et al. (2007), Italy & & & & & & & & & & & * \\
\hline
\end{tabular}




\section{Discussion}

The review provides a comprehensive examination of the perspectives of older patients in relation to communication about medications across transitions of care. Communication breakdowns were associated with medication discrepancies, specifically at the time of older patients' hospital discharge to the community. Older patients were frustrated with the lack of appropriate communication about their medications, especially when their medications were changed, or new medications were prescribed. There were differences between older patients' expectations of how medication communication should occur and what they experienced when they moved between different care settings. Older patients expected to receive information about changed medications before discharge and anticipated comprehensive communication between their PCPs and hospital providers, this did not always occur. For older patients, communication strategies that contributed to enhanced medication management comprised receiving written information about medications and medication education before discharge.

Older patients thought effective communication should occur between health professionals situated in hospitals and those in community settings, however these expectations were often not met. Similarly, older patients expected their PCPs to be well informed about their updated medications, and they also expected them to communicate regularly with their medical specialists; this communication did not always occur ${ }^{88}$.

Different insights into decision-making roles played by patients were identified. Some older patients were actively engaged in communicating with hospital staff about how to use post-discharge medications, while others experienced difficulties in asking questions. There were missed opportunities for health care providers in involving older patients in medication decision making ${ }^{50}$. The systematic review identified there were missed opportunities where health professionals could impact on improving communication about medications with older patients across transitions of care. There were opportunities for nurses or pharmacists to explain to older patients how medication changes were likely to affect therapeutic and unwanted effects. However, these interactions were rarely observed to occur ${ }^{50}$. Pharmacy staff tended to want to communicate with older patients on the day of admission when they were likely to be experiencing confusion, tiredness or affected by their state of illness. Alternatively, trying to communicate at discharge was also likely cause issues when patients were wanting to go home. There were missed opportunities for pharmacists to communicate during the patients' stay ${ }^{57}$. There were also missed opportunities with doctors who made decisions about discharge 
425 medications without listening to patients' accounts of their symptoms or family members' 426 concerns. Missed opportunities were also sometimes patient-related where patients thought that 427 they should have asked physicians more questions but they did not know what to ask ${ }^{53}$. Lack 428 of patient interest in being involved in the decision-making process could also be related to 429 their experiences with paternalism in the health care system ${ }^{89}$. A paternalistic environment 430 may result in health professionals not listening to older patients, health professionals not giving patients an opportunity to ask questions, and a failure to acknowledge variations in patients' health literacy, which affects their ability to comprehend medication information.

Older patients found particular communication strategies effective to support medication use across transitions of care. These strategies included receipt of written guides about discharge medications, plain language medication lists and clear explanations about medication changes. Explicit information justifying medication modifications to primary care providers has been found useful in simplifying complex medication regimens ${ }^{90}$. Interventions that involved patient-centred consultations, medication reconciliation on admission and discharge, post-discharge referrals to the community pharmacist or primary care for medication review or post-discharge phone follow-up have been shown to be effective strategies for reducing medication-related readmissions in older people ${ }^{56}$. Investigators of two intervention studies claimed that they implemented patient-centered interventions. However, there was insufficient clarification about how patients were involved in consultations or whether or not patients were at the center of the decision-making process ${ }^{56,78}$. Only one intervention study used a pharmacist-led motivational interviewing method as an example of patient-centred approach. This study emphasised that patient-centeredness can be achieved through counselling patients to explore their understanding of prescribed medications, their motivations and confidence to complete the medications as well as their perceived barriers to medication adherence $^{60}$. The term of patient-centeredness is becoming extensively used, but inadequately understood in the context of care transition of older patients. Patient-centeredness was sometimes conceived as sharing all decisions and information with patients. However, it sould involves encouraging patients to have opportunities to express their views and preferences about medication decisions ${ }^{91}$.

It is of value to relate the findings of this systematic review to theoretical insights of medication management relating to transitions of care. The Partnership Model advocates the need for continuous and accurate transfer of medication information across settings and between different episodes of care, in preventing medication errors ${ }^{92}$. The Medication 458 Communication Model suggests that the actual words used by health professionals such as 
"we” rather than just "I” and "you” can facilitate inclusive and open communication, which 460 provides the patient with opportunities to express concerns and needs about their medications 46193 . Therefore, partnerships amongst patients and health professionals can be maintained by open communication where all knowledge about medications are shared between individuals. It may help to facilitate patient-centered, shared decision making, which in turn improves medication safety in practice ${ }^{92,94}$. None of the papers used a conceptual framework to provide theoretical underpinnings regarding the phenomenon of interest ${ }^{95}$. The use of conceptual frameworks can help to ensure interventions contain particular components that then contribute implementation of successful interventions in relation to medication communication. For example, the use of the Shared Decision-making Model can help to elucidate understandings about interactions between pharmacists, physicians or nurses and patients and the ways in which decisions are made ${ }^{94}$. Models can also be used to consider situational factors such as time constraints and environmental issues in the decision-making process ${ }^{94}$. For instance, the Shared Decision Making Model (SDM) ${ }^{96}$ provides practical tools by recognizing the time that patients might need to study the new information about different options of medications and treatments. It also provides patient with interactive and patient-specific decision aids so that they can discuss their preferences with other people, including family members and friends at different times and different places, before arriving at final decisions with health care providers $^{96}$.

478

479

480

481

482

483

\subsection{Methodological Limitations of Included Studies}

Few qualitative papers comprehensively examined the patients' medication communication experiences with all health professional disciplines, but most focused on a single group, such as pharmacists or nurses, or they were conducted at single sites. Some interventions involved older patients with specific health conditions, such as heart failure or pneumonia. There was insufficient use of qualitative observational designs, which provides insight into what happens in actual settings. Of 12 qualitative studies, only one included patients from non-English speaking backgrounds. Intervention studies tended to focus on the discharge or post-discharge period, whereas only one study involved a multidisciplinary intervention comprising a patient-centred medication reconciliation program on admission and at discharge. Most studies examining communication across transitions of care were conducted in acute hospital settings, and rarely considered aged care facilities or used observational designs. According to MMAT results, the qualitative papers lacked information about the researchers' reflexivity in relation to the research process. For RCTs, the lack of clear 
description of randomisation or blinding was the underlying reason for lower scores, whereas

494 for other quantitative studies, low scores were associated with insufficient explanations about the sampling strategy.

\subsection{Limitations of the Systematic Review}

There are some limitations associated with the systematic review. Studies that were not in the English language were excluded. It was sometimes difficult to extract specific information about older patients’ perspectives on medication-related communication across transitions of care from studies that investigated a range of issues about transitions of care. Retrieved quantitative studies were very heterogenous in terms of aims, methodologies and outcome variables. It was therefore impossible to consider data pooling using meta-analysis.

\subsection{Implication for Practice and Future Research}

505

506

507

508

509

510

511

512

513

514

515

516

517

518

519

520

521

522

523

524

525

526

During management of medications, pharmacists and other health professionals need to use this activity as an opportunity to inform older patients about pending and existing changes to their medications. At key communication processes, such as ward rounds, bedside handovers and informal discussions with older patients, health professionals need to act as their advocates, asking them if they have any concerns about changes made to their medications, planning for transfers to other clinical settings and organising medication plans of care for discharge home. In health professionals acting as patients' advocates, there will be greater likelihood that patients will be able to be actively involved in making decisions about their medications and in speaking up if they have concerns. Pharmacists can also play a greater role in educating older patients about medications through repetition of straightforward instructions at each bedside visit, which contributes to patients' recall of fundamental medication knowledge. Older patients are more likely to be receptive to developing a more comprehensive understanding about their medications, which may encourage them to be more independent after discharge.

Taking into account older patients' views is a helpful way of addressing their concerns and promoting patient-centred care. This systematic review demonstrated that successful implementation of effective, tailored communication about medications requires a multidisciplinary approach with medical, pharmacist and nursing involvement, which leads to improved patient satisfaction and reduced hospital readmission after discharge. Multidisciplinary patient-centred medication education should be offered to older patients across each care transition point, from admission to discharge in order to encourage older 
patients' involvement. Health professionals should be aware that older patients' involvement in medication communication can be influenced by multiple factors during communication encounters. These factors include patients' health beliefs, health literacy, values, and perceptions of their own medical conditions, spatial factors of the care environment and providers' own attitudes towards older patients. In taking these factors into consideration, dedicated attention is needed in listening to older patients' concerns, asking questions to ensure their understanding of medications, and most importantly, adopting caring attitudes in establishing two-way communication.

Future studies could focus on examining the experiences of older patients who have language barriers and cognitive impairment. The conduct of observational studies should be considered to examine how environmental and sociocultural characteristics influence older patients' experiences of communication about medications across transitions of care ${ }^{93}$. Factors such as source of distractions, layouts of care settings and their impacts on the interactions between patient and health professionals can be better explored through observations. Environmental characteristics such as time of day, availability of health professionals in clinical settings would also be considered. Sociocultural characteristics could comprise older patients' beliefs and values about their relationships with health professionals, language spoken at home, coexisting health issues, their health literacy and knowledge about their medications, and ability to understand health professionals ${ }^{93,97}$. Individual factors including moods, attitudes and manners during the communication events, workload and time management skills of health professionals can help to identify enriching information about how older patients' experiences can be facilitated and optimized.

\section{Conclusions}

Communication about managing medication across transitions of care can be challenging and sometimes overlooked, when older patients are treated for multiple health conditions by diverse health professionals across settings. The systematic review identified communication breakdowns between hospital and community settings led not only to medication discrepancies, they also hindered older patients' self-medication management after discharge. Older patients valued timely and tailored verbal and written communication and receiving education from diverse health professionals when they moved between settings. Transitions of care do not comprise linear trajectories of patients' movements, with a starting and finishing point. Instead, they are endless loops of movements, where older patients can backtrack and move forward in 
560 different ways. Health professionals need to regularly consider older patients’ views across

561 transition of care, where often rapid and critical decisions are made about medications.

\section{Funding sources}

563 This research is funded by an Australian Research Council, Discovery Project Grant

564 (DP170100308).

\section{Conflicts of interest}

566 The authors have no conflict of interest to declare. 
1. Baillie L, Gallini A, Corser R, Elworthy G, Scotcher A, Barrand A. Care transitions for frail, older people from acute hospital wards within an integrated healthcare system in England: A qualitative case study. International Journal of Integrated Care. 2014;14. https://doi.org/10.5334/ijic.1175

2. McLeod LA. Patient transitions from inpatient to outpatient: Where are the risks? Can we address them? J. Healthc. Risk Manag. 2013;32:13. https://doi.org/10.1002/jhrm.21101

3. Gandara E, Moniz T, Ungar J, et al. Communication and information deficits in patients discharged to rehabilitation facilities: An evaluation of five acute care hospitals. J. Hosp. Med. 2009;4:E28-33. https://doi.org/10.1002/ihm.474

4. Glintborg B, Andersen SE, Dalhoff K. Insufficient communication about medication use at the interface between hospital and primary care. Qual Saf Health Care. 2007;16:34-39.

https://doi.org/10.1136/qshc.2006.019828

5. Witherington EM, Pirzada OM, Avery AJ. Communication gaps and readmissions to hospital for patients aged 75 years and older: observational study. Qual Saf Health Care. 2008;17:71-75. https://doi.org/10.1136/qshc.2006.020842

6. Akram F, Huggan PJ, Lim V, et al. Medication discrepancies and associated risk factors identified among elderly patients discharged from a tertiary hospital in Singapore. Singapore Med. J. 2015;56:379-384. https://doi.org/10.11622/smedj.2015108

7. Osorio SN, Abramson E, Pfoh ER, Edwards A, Schottel H, Kaushal R. Risk factors for unexplained medication discrepancies during transitions in care. Fam. Med. 2014;46:587-596. http://ezproxy.deakin.edu.au/login?url=http://search.ebscohost.com/login.aspx?direct=true\&db=md c\&AN=25163036\&site=eds-live\&scope=site

8. Manias $\mathrm{E}$, Hughes $\mathrm{C}$. Challenges of managing medications for older people at transition points of care. Res. Social Adm. Pharm. 2015;11:442-447. https://doi.org/10.1016/j.sapharm.2014.10.001

9. Cornu $\mathrm{P}$, Steurbaut $\mathrm{S}$, Leysen $\mathrm{T}$, et al. Effect of medication reconciliation at hospital admission on medication discrepancies during hospitalization and at discharge for geriatric patients. Ann. Pharmacother. 2012;46:484-494. https://doi.org/10.1345/aph.1Q594

10. Knez L, Suskovic S, Rezonja R, Laaksonen R, Mrhar A. The need for medication reconciliation: a crosssectional observational study in adult patients. Respir. Med. 2011;105 Suppl 1:S60-66.

https://doi.org/10.1016/S0954-6111(11)70013-0

11. Pippins JR, Gandhi TK, Hamann C, et al. Classifying and Predicting Errors of Inpatient Medication Reconciliation. J. Gen. Intern. Med. 2008,

http://ezproxy.deakin.edu.au/login?url=http://search.ebscohost.com/login.aspx?direct=true\&db=eds gao\&AN=edsgcl.231189950\&authtype=sso\&custid=deakin\&site=eds-live\&scope=site: 1414 .

12. Cornish PL, Knowles SR, Marchesano R, et al. Unintended Medication Discrepancies at the Time of Hospital Admission. Arch. Intern. Med. 2005;165:424-429. https://doi.org/10.1001/archinte.165.4.424

13. NCCMERP. About Medication Errors: What is a Medication Error?, https://www.nccmerp.org/aboutmedication-errors: The National Coordinating Council for Medication Error Reporting and Prevention; 2020.

14. Van Den Bemt PMLA, Van Der Schrieck-De Loos EM, Van Der Linden C, Theeuwes AMLJ, Pol AG. Effect of medication reconciliation on unintentional medication discrepancies in acute hospital admissions of elderly adults: A multicenter study. J. Am. Geriatr. Soc. 2013;61:1262-1268.

https://doi.org/10.1111/igs.12380

15. Cornish PL, Knowles SR, Shadowitz S, et al. Unintended Medication Discrepancies at the Time of Hospital Admission. Arch. Intern. Med. 2005;165:424-429. https://doi.org/10.1001/archinte.165.4.424

16. Tam VC, Knowles SR, Cornish PL, Fine N, Marchesano R, Etchells EE. Frequency, type and clinical importance of medication history errors at admission to hospital: a systematic review. Can. Med. Assoc. J. 2005;173:510-515. https://doi.org/10.1503/cmaj.045311

17. De Boer A, Lau HS, Florax C, Porsius AJ. The completeness of medication histories in hospital medical records of patients admitted to general internal medicine wards. Br. J. Clin. Pharmacol. 2000;49:597603. https://doi.org/10.1046/i.1365-2125.2000.00204.x

18. Sullivan C, Gleason KM, Rooney D, Groszek JM, Barnard C. Medication reconciliation in the acute care setting - Opportunity for nursing and challenge. J. Nurs. Care Qual. 2005;20:95-98.

https://doi.org/10.1097/00001786-200504000-00001 
19. Manias E, Gerdtz MF, Weiland TJ, Collins M. Medication Use Across Transition Points from the Emergency Department: Identifying Factors Associated with Medication Discrepancies. Ann. Pharmacother. 2009;43:1755-1764. https://doi.org/10.1345/aph.1M206

20. Bridgeman PJ, Rynn KO. Medication reconciliation in the emergency department. Am. J. Health Syst. Pharm. 2008;65:2325-2326. https://doi.org/10.2146/ajhp080199

21. Manias E, Gerdtz M, Williams A, McGuiness J, Dooley M. Communicating about the management of medications as patients move across transition points of care: an observation and interview study. J. Eval. Clin. Pract. 2016;22:635-643. https://doi.org/10.1111/jep.12507

22. Surbhi S, Munshi KD, Bell PC, Bailey JE. Drug therapy problems and medication discrepancies during care transitions in super-utilizers. J. Am. Pharm. Assoc. (2003). 2016;56:633-642.

https://doi.org/10.1016/j.japh.2016.07.004

23. Flora DS, Parsons PL, Slattum PW. Managing Medications for Improved Care Transitions. Generations. 2011;35:37-42.

http://ezproxy.deakin.edu.au/login?url=http://search.ebscohost.com/login.aspx?direct=true\&db=pb h\&AN=72679373\&site=eds-live\&scope=site

24. Levenson SA, Saffel DA. The Consultant Pharmacist and the Physician in the Nursing Home: Roles, Relationships, and a Recipe for Success. J. Am. Med. Dir. Assoc. 2007;8:55-64.

https://doi.org/10.1016/i.jamda.2006.11.002

25. American Pharmacists A, American Society of Health-System P. Improving care transitions: Optimizing medication reconciliation. J. Am. Pharm. Assoc. (2003). 2012;52:e43-e52.

https://doi.org/10.1331/JAPhA.2012.12527

26. Holland DM. Interdisciplinary collaboration in the provision of a pharmacist-led discharge medication reconciliation service at an Irish teaching hospital. Int. J. Clin. Pharm. 2015;37:310-319.

https://doi.org/10.1007/s11096-014-0059-y

27. Wittkowsky AK. Impact of target-specific oral anticoagulants on transitions of care and outpatient care models. J. Thromb. Thrombolysis. 2013;35:304-311. https://doi.org/10.1007/s11239-013-0879-y

28. Chhabra PT, Rattinger GB, Dutcher SK, Hare ME, Parsons KL, Zuckerman IH. Medication reconciliation during the transition to and from long-term care settings: A systematic review. Research in Social and Administrative Pharmacy. 2012,

http://ezproxy.deakin.edu.au/login?url=http://search.ebscohost.com/login.aspx?direct=true\&db=eds gao\&AN=edsgcl.277195235\&authtype=sso\&custid=deakin\&site=eds-live\&scope=site:60.

29. Kristeller J. Transition of Care: Pharmacist Help Needed. Hosp. Pharm. 2014;49:215-216. https://doi.org/10.1310/hpj4903-215

30. Kourkouta L, Papathanasiou IV. Communication in nursing practice. Mater Sociomed. 2014;26:65-67. https://doi.org/10.5455/msm.2014.26.65-67

31. Chard R, Makary MA. Transfer-of-Care Communication: Nursing Best Practices. AORN J. 2015;102:329-339. https://doi.org/10.1016/j.aorn.2015.07.009

32. Knight DA, Thompson D, Mathie E, Dickinson A. 'Seamless care? Just a list would have helped!' older people and their carer's experiences of support with medication on discharge home from hospital. Health Expectations: An International Journal of Public Participation in Health Care \& Health Policy. 2013;16:277-291.

http://search.ebscohost.com/login.aspx?direct=true\&AuthType=sso\&db=psyh\&AN=2013-29393008\&site=ehost-live\&scope=site\&authtype=sso\&custid=deakin d.knight@herts.ac.uk

33. Manias E, Gerdtz M, Williams A, Dooley M. Complexities of medicines safety: communicating about managing medicines at transition points of care across emergency departments and medical wards. $J$. Clin. Nurs. 2015;24:69-80. https://doi.org/10.1111/jocn.12685

34. Lingaratnam S, Aranda S, Pearce T, Kirsa S. A controlled before and after study to evaluate a patient and health professional partnership model towards effective medication reconciliation. J. Oncol. Pharm. Pract. 2013;19:48-56. https://doi.org/10.1177/1078155212451936

35. Halapy $\mathrm{H}$, Kertland $\mathrm{H}$. Ascertaining problems with medication histories. The Canadian journal of hospital pharmacy. 2012;65:360-367. https://doi.org/10.4212/cjhp.v65i5.1173

36. APAC.Guiding principles to achieve continuity in medication management 2005 . https://www1.health.gov.au/internet/main/publishing.nsf/650f3eec0dfb990fca25692100069854/eea 5b39aa0a63f18ca257bf0001dae08/\$FFILE/Guiding-principles-to-achieve-continuity-in-medicationmanagement.pdf

37. Shaw T, Hines M, Kielly-Carroll C.Impact of Digital Health on the Safety and Qualityof Health CareSydney:2017 
651

652

653

654

655

656

657

658

659

660

661

662

663

664

665

666

667

668

669

670

671

672

673

674

675

676

677

678

679

680

681

682

683

684

685

686

687

688

689

690

691

692

693

694

695

696

697

698

699

700

701

702

703

704

705

706

707

38. Graber ML, Siegal D, Riah H, Johnston D, Kenyon K. Electronic Health Record-Related Events in Medical Malpractice Claims. Journal of Patient Safety. 2019;15:77-85.

https://doi.org/10.1097/pts.0000000000000240

39. Kripalani S, LeFevre F, Phillips CO, Williams MV, Basaviah P, Baker DW. Deficits in communication and information transfer between hospital-based and primary care physicians: Implications for patient safety and continuity of care. JAMA, The Journal of the American Medical Association. 2007, http://ezproxy.deakin.edu.au/login?url=http://search.ebscohost.com/login.aspx?direct=true\&db=eds gao\&AN=edsgcl.162080128\&authtype=sso\&custid=deakin\&site=eds-live\&scope=site:831.

40. Allen J, Hutchinson AM, Brown R, Livingston PM. Quality care outcomes following transitional care interventions for older people from hospital to home: a systematic review. BMC Health Serv. Res. 2014; 10.1186/1472-6963-14-346. https://doi.org/10.1186/1472-6963-14-346

41. Soares MM, Jacobs K, Laugaland K, Aase K, Barach P. Interventions to improve patient safety in transitional care - a review of the evidence. Work. 2012;41:2915-2924. https://doi.org/10.3233/WOR2012-0544-2915

42. LaMantia MA, Scheunemann LP, Viera AJ, Busby-Whitehead J, Hanson LC. Interventions to Improve Transitional Care Between Nursing Homes and Hospitals: A Systematic Review. 2010; 10.1111/j.15325415.2010.02776.x:777. https://doi.org/10.1111/j.1532-5415.2010.02776.x

43. Albert NM. A systematic review of transitional-care strategies to reduce rehospitalization in patients with heart failure. Heart and Lung: Journal of Acute and Critical Care. 2016;45:100-113.

https://doi.org/10.1016/i.hrtlng.2015.12.001

44. Puhr MI, Thompson HJ. The use of transitional care models in patients with stroke. J. Neurosci. Nurs. 2015;47:223. https://doi.org/10.1097/JNN.0000000000000143

45. Schell W. A review: Discharge navigation and its effect on heart failure readmissions. Professional Case Management. 2014;19:224-234. https://doi.org/10.1097/NCM.0000000000000040

46. Spinewine A, Claeys C, Foulon V, Chevalier P. Approaches for improving continuity of care in medication management: A systematic review. Int. J. Qual. Health Care. 2013;25:403-417. https://doi.org/10.1093/intqhc/mzt032

47. Kostas T, Paquin AM, Zimmerman K, Simone M, Skarf LM, Rudolph JL. Characterizing medication discrepancies among older adults during transitions of care: a systematic review focusing on discrepancy synonyms, data sources and classification terms. Aging Health. 2013;

10.2217/ahe.13.47:497. https://doi.org/10.2217/ahe.13.47

48. Mansah M, Fernandez R, Griffiths R, Chang E. Effectiveness of strategies to promote safe transition of elderly people across care settings. JBI Library of Systematic Reviews. 2009;7:1036.

https://doi.org/http://ezproxy.deakin.edu.au/login?url=http://search.ebscohost.com/login.aspx?dire ct=true\&db=ccm\&AN=113589540\&authtype=sso\&custid=deakin\&site=eds-live\&scope=site

49. Hias J, Van der Linden L, Spriet I, et al. Predictors for unintentional medication reconciliation discrepancies in preadmission medication: a systematic review. Eur. J. Clin. Pharmacol. 2017;73:13551377. https://doi.org/10.1007/s00228-017-2308-1

50. Bolster D, Manias E. Person-centred interactions between nurses and patients during medication activities in an acute hospital setting: qualitative observation and interview study. Int. J. Nurs. Stud. 2010;47:154-165. https://doi.org/10.1016/j.ijnurstu.2009.05.021

51. Moher D, Liberati A, Tetzlaff J, G. Altman D. Preferred reporting items for systematic reviews and meta-analyses: the PRISMA statement. BMJ: British Medical Journal. 2009;339:332.

http://ezproxy.deakin.edu.au/login?url=http://search.ebscohost.com/login.aspx?direct=true\&db=eds jsr\&AN=edsjsr.25672329\&authtype=sso\&custid=deakin\&site=eds-live\&scope=site

52. Hong QN, Bartlett G, Vedel I, et al. The Mixed Methods Appraisal Tool (MMAT) version 2018 for information professionals and researchers. Education for Information. 2018;34:285-291.

https://doi.org/10.3233/EFI-180221

53. Allen J, Hutchinson AM, Brown R, Livingston PM. User experience and care for older people transitioning from hospital to home: Patients' and carers' perspectives. Health Expect. 2018;21:518-

527. https://doi.org/10.1111/hex.12646

54. Chiu PK, Lee AW, See TY, Chan FH. Outcomes of a pharmacist-led medication review programme for hospitalised elderly patients. Hong Kong Med. J. 2018;24:98-106.

https://doi.org/10.12809/hkmj176871

55. Gadbois EA, Tyler DA, Shield R, et al. Lost in Transition: a Qualitative Study of Patients Discharged from Hospital to Skilled Nursing Facility. J. Gen. Intern. Med. 2018; 10.1007/s11606-018-4695-0. https://doi.org/10.1007/s11606-018-4695-0 
56. Barnett NL, Dave K, Athwal D, Parmar P, Kaher S, Ward C. Impact of an integrated medicines

57. Jeffs L, Saragosa M, Law M, et al. Elucidating the information exchange during interfacility care transitions: Insights from a Qualitative Study. BMJ Open. 2017;7:e015400. https://doi.org/10.1136/bmjopen-2016-015400

58. McAiney CA, Hillier LM, Paul J, et al. Improving the seniors' transition from hospital to the community: a case for intensive geriatric service workers. Int. Psychogeriatr. 2017;29:149-163.

https://doi.org/10.1017/S1041610216001058

59. Bayliss EA, McQuillan DB, Ellis JL, et al. Using Electronic Health Record Data to Measure Care Quality for Individuals with Multiple Chronic Medical Conditions. J. Am. Geriatr. Soc. 2016;64:1839-1844. https://doi.org/10.1111/igs.14248

60. Eyler R, Shvets K, Blakely ML. Motivational interviewing to increase postdischarge antibiotic adherence in older adults with pneumonia. Consult. Pharm. 2016;31:38-43.

https://doi.org/10.4140/TCP.n.2016.38

61. O'Kula SS, Gottesman E, Jones S, Signor D, Hung WW, Boockvar KS. Transitional care outcomes in older Spanish-English bilingual veterans. J. Am. Geriatr. Soc. 2016;64:1132-1133.

https://doi.org/10.1111/igs.14116

62. Rustad EC, Furnes B, Dysvik E, Cronfalk BS. Older patients' experiences during care transition. Patient Preference and Adherence. 2016;10:769-779. https://doi.org/10.2147/PPA.S97570

63. Wong C, Hogan DB. Care transitions: Using narratives to assess continuity of care provided to older patients after hospital discharge. Canadian Geriatrics Journal. 2016;19:97-102.

https://doi.org/10.5770/cgi.19.229

64. Bagge M, Norris $\mathrm{P}$, Heydon $\mathrm{S}$, Tordoff J. Older people's experiences of medicine changes on leaving hospital. Res. Social Adm. Pharm. 2014;10:791-800. https://doi.org/10.1016/i.sapharm.2013.10.005

65. Hvidt LN, Hvidt KN, Madsen K, Schmidt TA. Comprehension deficits among older patients in a quick diagnostic unit. Clin. Interv. Aging. 2014;9:705-710. https://doi.org/10.2147/CIA.S61850

66. Lindquist LA, Lindquist LM, Zickuhr L, Friesema E, Wolf MS. Unnecessary complexity of home medication regimens among seniors. Patient Educ. Couns. 2014;96:93-97.

https://doi.org/10.1016/i.pec.2014.03.022

67. Blennerhassett J, Hilbers J. Medicine management in older people from non-english speaking backgrounds. Journal of Pharmacy Practice and Research. 2011;41:33-36.

https://doi.org/10.1002/i.2055-2335.2011.tb00063.x

68. Knight DA, Thompson D, Mathie E, Dickinson A. 'Seamless care? Just a list would have helped!' older people and their carer's experiences of support with medication on discharge home from hospital. Health Expectations: An International Journal of Public Participation in Health Care \& Health Policy. 2011;16:277-291. https://doi.org/10.1111/j.1369-7625.2011.00714.x

69. Arora VM, Prochaska ML, Farnan JM, et al. Problems after discharge and understanding of communication with their primary care physicians among hospitalized seniors: a mixed methods study. J. Hosp. Med. 2010;5:385-391. https://doi.org/10.1002/ihm.668

70. Mesteig M, Helbostad JL, Sletvold O, Rosstad T, Saltvedt I. Unwanted incidents during transition of geriatric patients from hospital to home: a prospective observational study. BMC Health Serv. Res. 2010;10:1-9. https://doi.org/10.1186/1472-6963-10-1

71. Dedhia $\mathrm{P}$, Kravet $\mathrm{S}$, Bulger J, et al. A quality improvement intervention to facilitate the transition of older adults from three hospitals back to their homes. J. Am. Geriatr. Soc. 2009;57:1540-1546.

https://doi.org/10.1111/i.1532-5415.2009.02430.x

72. Del Sindaco D, Pulignano G, Minardi G, et al. Two-year outcome of a prospective, controlled study of a disease management programme for elderly patients with heart failure. J. Cardiovasc. Med.

(Hagerstown). 2007;8:324-329. https://doi.org/10.2459/JCM.0b013e32801164cb

73. Flacker J, Park W, Sims A. Hospital discharge information and older patients: Do they get what they need? J. Hosp. Med. 2007;2:291-296. https://doi.org/10.1002/jhm.166

74. Spinewine A, Swine C, Dhillon $S$, et al. Effect of a collaborative approach on the quality of prescribing for geriatric inpatients: a randomized, controlled trial. J. Am. Geriatr. Soc. 2007;55:658-665. https://doi.org/10.1111/j.1532-5415.2007.01132.x

75. Lopez Cabezas C, Falces Salvador C, Cubi Quadrada D, et al. Randomized clinical trial of a postdischarge pharmaceutical care program vs regular follow-up in patients with heart failure. Farm Hosp. 2006;30:328-342. https://doi.org/10.1097/00005650-199806000-00013 
801

802

803

804

805

806

807

808

809

810

811

812

813

814

815

816

817

818

819

820

821

76. Shen Q, Karr M, Ko A, Chan DK, Khan R, Duvall D. Evaluation of a medication education program for elderly hospital in-patients. Geriatr. Nurs. 2006;27:184-192.

https://doi.org/10.1016/j.gerinurse.2006.03.015

77. Enguidanos SM, Brumley RD. Risk of medication errors at hospital discharge and barriers to problem resolution. Home Health Care Serv. Q. 2005;24:123-135. https://doi.org/10.1300/J027v24n01 09

78. Coleman EA, Smith JD, Frank JC, Min SJ, Parry C, Kramer AM. Preparing patients and caregivers to participate in care delivered across settings: the Care Transitions Intervention. J. Am. Geriatr. Soc. 2004;52:1817-1825. https://doi.org/10.1111/j.1532-5415.2004.52504.x

79. Sexton J, Brown A. Problems with medicines following hospital discharge: Not always the patient's fault? J. Soc. Adm. Pharm. 1999;16:199-207. http://ovidsp.ovid.com/ovidweb.cgi?T=JS\&PAGE=reference\&D=emca1\&NEWS=N\&AN=30123725

80. Clare J, Hofmeyer A. Discharge planning and continuity of care for aged people: indicators of satisfaction and implications for practice. Aust. J. Adv. Nurs. 1998;16:7-13.

https://doi.org/http://ezproxy.deakin.edu.au/login?url=http://search.ebscohost.com/login.aspx?dire $\mathrm{ct}=$ true\&db=edselc\&AN=edselc.2-52.0-0032161973\&authtype=sso\&custid=deakin\&site=edslive\&scope=site.

81. Leduc N, Tannenbaum TN, Bergman H, Champagne F, Clarfield AM, Kogan S. Compliance of frail elderly with health services prescribed at discharge from an acute-care geriatric ward. Med. Care. 1998;36:904-914. https://doi.org/10.1097/00005650-199806000-00013

82. Rich MW, Gray DB, Beckham V, Wittenberg C, Luther P. Effect of a multidisciplinary intervention on medication compliance in elderly patients with congestive heart failure. Am. J. Med. 1996;101:270276. https://doi.org/https://doi.org/10.1016/S0002-9343(96)00172-6

83. Burns JM, Sneddon I, Lovell M, McLean A, Martin BJ. Elderly patients and their medication: a postdischarge follow-up study. Age Ageing. 1992;21:178-181. https://doi.org/10.1093/ageing/21.3.178

84. Cochrane RA, Mandal AR, Ledger-Scott M, Walker R. Changes in drug treatment after discharge from hospital in geriatric patients. Br. Med. J. 1992;305:694-696.

https://doi.org/https://www.jstor.org/stable/29717006

85. German PS, Klein LE, McPhee SJ, Smith CR. Knowledge of and compliance with drug regimens in the elderly. J. Am. Geriatr. Soc. 1982;30:568-571. https://doi.org/10.1111/j.1532-5415.1982.tb05663.x

86. Braun V, Clarke V. Using thematic analysis in psychology. Qualitative Research in Psychology. 2006;3:77-101. https://doi.org/10.1191/1478088706qp063oa

87. Boyce LE, Knight AT. Audit of General Practitioner Medication Lists for Older Patients at a Regional Hospital. Journal of Pharmacy Practice \& Research. 2013;43:105.

https://doi.org/http://dx.doi.org/dx.doi.org/108

88. Van Blijswijk SCE, de Waard CS, van Peet PG, et al. Wishes and needs of community-dwelling older persons concerning general practice: A qualitative study. PLoS One. 2018; 10.1371/journal.pone.0200614. https://doi.org/10.1371/journal.pone.0200614

89. Jung HP, Grol R, Wensing M, Baerveldt C, Olesen F. Patient characteristics as predictors of primary health care preferences: A systematic literature analysis. Health Expect. 2003;6:160-181. https://doi.org/10.1046/j.1369-6513.2003.00221.x

90. Stange D, Kriston L, von-Wolff A, Baehr M, Dartsch DC. Reducing cardiovascular medication complexity in a German university hospital: effects of a structured pharmaceutical management intervention on adherence. J. Manag. Care Pharm. 2013;19:396-407.

https://doi.org/10.18553/imcp.2013.19.5.396

91. Stewart M. Towards a global definition of patient centred care: the patient should be the judge of patient centred care,

http://ezproxy.deakin.edu.au/login?url=http://search.ebscohost.com/login.aspx?direct=true\&db=eds gao\&AN=edsgcl.71820692\&authtype=sso\&custid=deakin\&site=eds-live\&scope=site: British Medical Association; 2001.

92. APAC. Guiding principles to achieve continuity in medication management: Australian Pharmaceutical Advisory Council; 2005.

http://ezproxy.deakin.edu.au/login?url=http://search.ebscohost.com/login.aspx?direct=true\&db=cat 00097a\&AN=deakin.b2136517\&authtype=sso\&custid=deakin\&site=eds-live\&scope=site

http://www.health.gov.au/internet/main/publishing.nsf/Content/4182D79CFCB23CA2CA25738E001B94C2/\$ Fi le/guiding.pdf

93. Manias E. Medication communication: a concept analysis. J. Adv. Nurs. 2010;66:933-943. https://doi.org/10.1111/i.1365-2648.2009.05225.x 
94. Liu W, Manias E, Gerdtz M. Understanding medication safety in healthcare settings: a critical review of conceptual models. Vol 182011:290-302.

95. Graham ID, Tetroe J, Group KTR. Some Theoretical Underpinnings of Knowledge Translation. 2007;14:936-941. https://doi.org/10.1111/j.1553-2712.2007.tb02369.x

96. Elwyn G, Frosch D, Thomson R, et al. Shared Decision Making: A Model for Clinical Practice. J. Gen. Intern. Med. 2012;27:1361-1367. https://doi.org/10.1007/s11606-012-2077-6

97. Borrott N, Kinney S, Newall F, et al. Medication communication between nurses and doctors for paediatric acute care: An ethnographic study. J. Clin. Nurs. 2017;26:1978.

831 https://doi.org/10.1111/jocn.13606 